\title{
A Late Eocene age proposal for the Loreto Formation (Brunswick Peninsula, southernmost Chile), based on fossil cartilaginous fishes, paleobotany and radiometric evidence
}

\author{
Rodrigo A. Otero ${ }^{1}$, Teresa Torres ${ }^{2}$, Jacobus P. Le Roux ${ }^{3}$, Francisco Hervé ${ }^{4}$, C. Mark Fanning ${ }^{5}$, \\ Roberto E. Yury-Yáñez ${ }^{6}$, David Rubilar-Rogers ${ }^{7}$
}

\author{
${ }^{1}$ Consejo de Monumentos Nacionales, Av. Vicuña Mackenna 084, Providencia, Santiago, Chile. \\ paracrioceras@gmail.com \\ ${ }^{2}$ Facultad de Ciencias Agronómicas, Universidad de Chile, Av. Santa Rosa 11315, Santiago, Chile. \\ terexylon@gmail.com \\ ${ }^{3}$ Departamento de Geología, Facultad de Ciencias Físicas y Matemáticas, Universidad de Chile, Plaza Ercilla 803, Santiago, Chile. \\ jroux@cec.uchile.cl \\ ${ }^{4}$ Escuela de Ciencias de la Tierra, Facultad de Ingeniería, Universidad Nacional Andrés Bello, Sazie 2350, Santiago, Chile. \\ fherve@unab.cl \\ ${ }^{5}$ Research School of Earth Sciences, Australian National University, Canberra, Australia. \\ Mark.Fanning@anu.edu.au \\ ${ }^{6}$ Laboratorio de Zoología de Vertebrados, Departamento de Ciencias Ecológicas, Facultad de Ciencias, Universidad de Chile, \\ Las Palmeras 3425, Ñunoa, Santiago, Chile. \\ robyury@ug.uchile.cl \\ ${ }^{7}$ Área Paleontología, Museo Nacional de Historia Natural, Casilla 787, Santiago, Chile. \\ drubilar@mnhn.cl
}

\begin{abstract}
We present new data on the paleoichthyology, paleobotany and radiometric results of the Loreto Formation in the Brunswick Peninsula of southernmost Chile, that allow us to propose a Late Eocene age. The rich diversity of fossil cartilaginous fishes (Chondrichthyes, Elasmobranchii) recognized in upper levels of this unit includes the taxa Carcharias aff. 'hopei' (Agassiz), Odontaspis sp., Carcharoides catticus (Philippi), Striatolamia macrota (Agassiz), Anomotodon sp., Macrorhizodus praecursor (Leriche), Galeorhinus sp., Abdounia sp., Hexanchus sp., Squatina sp., Hexanchidae indet., Myliobatis sp., Myliobatoidea indet., and Ischyodus dolloi Leriche. This assemblage has clear ecological affinities with Eocene Tethyan fauna previously described in the Northern Hemisphere, and also has common elements with Eocene cartilaginous fishes from Antarctica. Additionally, a paleobotanic study of this unit identified leaf imprints of Asplenium sp., Pteris sp., Podocarpus sp., and abundant angiosperms including Nothofagus lanceolata Dusén, $N$. simplicidens Dusén, $N$. variabilis Dusén, $N$. cf. alessandri Espinosa, N. subferruginea (Dusén), Hydrangea sp. and Phyllites spp. Wood remains of Nothofagoxylon scalariforme Gothan and Araucariaceae cf. Araucarioxylon Kraus were also identified. Additionally, pollen grains indicate gymnosperms and angiosperms: Podocarpidites otagoensis Couper, Retitricolpites sp., Tricolpites sp., Liliacidites sp., Polyporina sp., Nothofagidites cincta Cookson, and Nothofagidites cranwellae Couper, having affinities with Eocene florae, and being consistent with the age of the fossil fishes. Finally, a SHRIMP U-Th-Pb analysis of two samples collected from the studied beds provided thirty-eight and sixty zircon grains, indicating a clear main peak at 36.48 $\pm 0.47 \mathrm{Ma}(\mathrm{MSWD}=1.5)$ and $36,73 \pm 0.50 \mathrm{Ma}(\mathrm{MSWD}=0.65)$. The integrated results indicate that the upper part of the Loreto Formation has a minimum Priabonian age, supporting previous reassignations of this part of the formation into the Late Eocene, and differing from the Oligocene age proposed in its original definition.
\end{abstract}


RESUMEN Una edad eocena tardía propuesta para la Formación Loreto (península de Brunswick, extremo sur de Chile), basada en peces cartilaginosos fósiles, paleobotánica y evidencia radiógena. El presente estudio integra nueva evidencia paleoictiológica, paleobotánica y resultados radiométricos que en conjunto permiten proponer una edad eocena tardía para la Formación Loreto, en la península de Brunswick del extremo sur de Chile. La rica diversidad de peces cartilaginosos fósiles (Chondrichthyes, Elasmobranchii) reconocida en niveles superiores de la mencionada unidad incluye los taxa Carcharias aff. hopei (Agassiz), Odontaspis sp., Carcharoides catticus (Philippi), Striatolamia macrota (Agassiz), Anomotodon sp., Macrorhizodus praecursor (Leriche), Galeorhinus sp., Abdounia sp., Hexanchus sp., Squatina sp., Hexanchidae indet., Myliobatis sp., Myliobatoidea indet., e Ischyodus dolloi Leriche. Este conjunto muestra claras afinidades ecológicas con ictiofaunas del Eoceno tethyano previamente descritas en el Hemisferio Norte, a la vez que presenta elementos comunes con peces cartilaginosos del Eoceno de Antártica. Adicionalmente, el estudio paleobotánico en esta unidad identificó improntas referidas a Asplenium sp., Pteris sp. Podocarpus sp., y abundantes angiospermas, incluyendo Nothofagus lanceolata Dusén, $N$. simplicidens Dusén, $N$. variabilis Dusén, $N$. cf. alessandri Espinosa, N. subferruginea (Dusén), Hydrangea sp. y Phyllites spp. Además, se identificaron restos de troncos fósiles de Nothofagoxylon scalariforme Gothan y Araucariaceae cf. Araucarioxylon Kraus. Adicionalmente, se reconoció polen de las gimnospermas y angiospermas: Podocarpidites otagoensis Couper, Retitricolpites sp., Tricolpites sp., Liliacidites sp., Polyporina sp., Nothofagidites cincta Cookson y Nothofagidites cranwellae Couper, las que presentan afinidades con floras de edad eocena, siendo consistente con la edad de los peces fósiles. Finalmente, el análisis SHRIMP U-Th-Pb de dos muestras colectadas desde los estratos estudiados, han proporcionado 38 y 60 granos de circón respectivamente, indicando claros peaks principales en $36,48 \pm 0,47 \mathrm{Ma}(\mathrm{MSWD}=1,5)$ y $36,73 \pm 0,50 \mathrm{Ma}(\mathrm{MSWD}=0,65)$. Los resultados integrados indican que los estratos superiores de la Formación Loreto pueden ser acotados a una mínima edad priaboniana, siendo consistente con reasignaciones previas al Eoceno Tardío para esta parte de la formación, y difiriendo de la edad oligocena originalmente propuesta en su definición.

Palabras clave: Peces cartilaginosos fósiles, Paleobotánica, Shrimp U-Th-Pb, Priaboniano, Formación Loreto, Extremo sur de Chile.

\section{Introduction}

The Loreto Formation (Hoffstetter et al., 1957) was previously known by several different informal names such as 'Araucaria Stufe', 'Arenaense', 'Banco de Gastrópodos', 'Banco de Venus', 'Capas de Loreto', 'Fagus Stufe', 'Magallaniano', 'Magallaniense', 'Magellanian beds', etc. The first reference to these strata as the 'Loreto Formation' was in Hoffstetter et al. (1957), who proposed an Eocene age, but the description and definition of the unit was much generalized. Fasola (1969) was the first to propose a type locality and paralocalities for the Loreto Formation in the Los Ciervos River, Lynch River and Las Minas River valleys. This author measured a stratigraphic column in each of these areas and constructed a composite section showing sandstones with variable grain size and hardness, together with sporadic clay, conglomerate, concretionary and fossiliferous beds including carbonized wood, assigned by this author to the Oligocene based on palynomorphs. Subsequently, Charrier and Lahsen (1969) proposed a stratigraphic correlation chart indicating a Late Eocene age for the base of the Loreto Formation, while the rest of the formation remained in the Oligocene.
Since previous studies do not allow the age of the Loreto Fomation to be precisely defined, this paper aims to constrain the age of this unit based on three available sources of information: i. An abundant fossil assemblage of cartilaginous fish teeth hosted by one particular bed in the studied locality, made it possible to obtain enough samples to interpret the different dental shapes belonging to certain genera and species. In this way, identifications based on isolated elements that usually lead to dubious taxonomical interpretations could be avoided. The identified taxa include several genera and species with good chronostratigraphic resolution; ii. Leaf imprints, wood remains and palynomorphs were collected from beds occurring stratigraphically below the teeth-rich beds; iii. In addition to the relative age obtained from the paleontological evidence, an absolute age of approximately 36-37 Ma was obtained by SHRIMP U-Th-Pb dating of detrital zircons.

Considering that the studied section of the Loreto Formation corresponds to its upper portion, and based on the new evidence presented here, a Late Eocene (Priabonian) age for most of the Loreto Formation can be proposed. This is the first age based on integrated and diverse data obtained from well-defined stratigraphic units within the formation. 


\section{Locality and geological setting}

\subsection{Locality}

The studied materials were discovered during January 2007 and January 2008 in the Magallanes Reserve (530.' $18^{\circ}$ 'S $\left.71^{\circ} 03^{\prime} 32^{\prime \prime} \mathrm{W}\right)$, administrated by the Corporación Nacional Forestal (Conaf), located about $10 \mathrm{~km}$ west of Punta Arenas, in the Brunswick Peninsula (Fig. 1A). The host beds crop out on the upper slopes of the Las Minas River valley (locally known as Río de Las Minas, so called hereafter in the text). The studied succession forms part of the Loreto Formation (Hoffstetter et al., 1957) assigned by these authors to the Eocene-Miocene, and later redefined and reassigned by Fasola (1969) to the Oligocene based on palynomorphs. The exposed lithology includes a coquina bed with abundant but poorly preserved oysters at the base of the valley slope, and several coal seams with frequent leaf imprints and carbonized wood remains exposed near the top, intercalated with strata that include fossil vertebrate remains. All these beds are consistent with the description of the Carbonoso Member of Hemmer (1935), as cited by Hoffstetter et al. (1957). In addition, the studied beds coincide with level K of Fasola (1969; Figs. 1 and 2), suggested by the latter author to belong to the upper portion of his measured stratigraphic section.

\subsection{Geological setting}

The geology of the Brunswick Peninsula is characterized by thick sedimentary successions with a general SE strike, exposing the different units with decreasing age towards the NE (Fig. 1B). From the SW part of the peninsula to the NE (older to younger), the recognized units are, from top to base:

Chorrillo Chico Formation (Thomas, 1949): This is a $275 \mathrm{~m}$ thick succession (Charrier and Lahsen, 1968) of light brown, compact argillites, with sporadic lenses of glauconitic sandstones and lenticular, calcareous concretions. Charrier and Lahsen $(1968,1969)$ assigned the formation to the Late Maastrichtian-Early Paleocene, the lower limit being defined by the age of the Carrera Formation. A section of this formation was studied in the western part of Brunswick Peninsula, providing 27 taxa of dinoflagellates that support a middle to Late Paleocene age for this unit (Quatrocchio and Sarjeant, 2003).

San Jorge Formation (Thomas, 1949): This succession (about $400 \mathrm{~m}$ thick), is exposed along the eastern coast of the Brunswick Peninsula, about $2 \mathrm{~km}$ north of Punta Carrera. It is formed by soft-weathering brown argillites with abundant concretionary nodules of limestone and scarce fossils. The age proposed by Charrier and Lahsen (1969) is
A

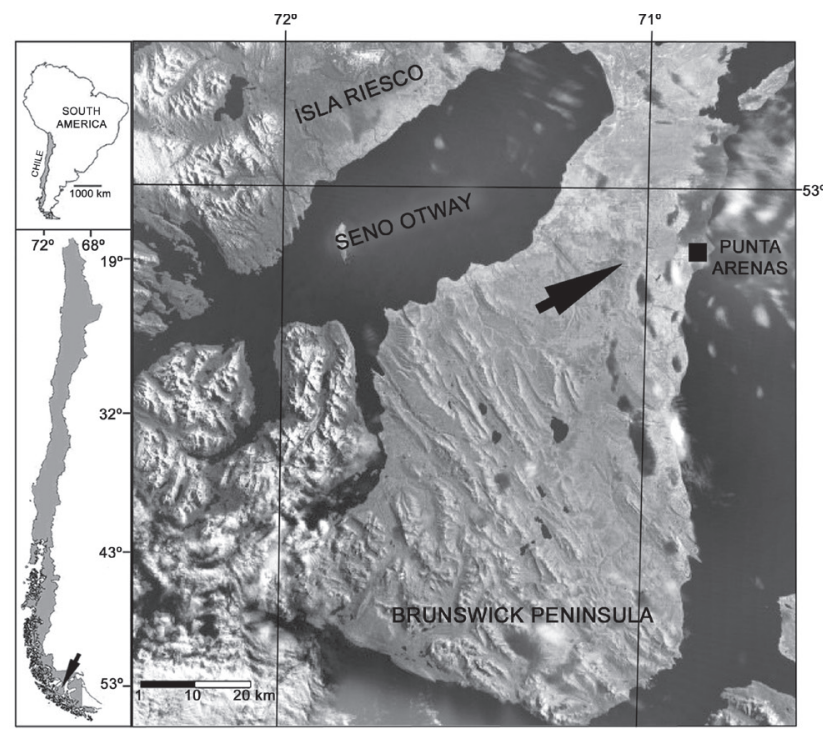

B

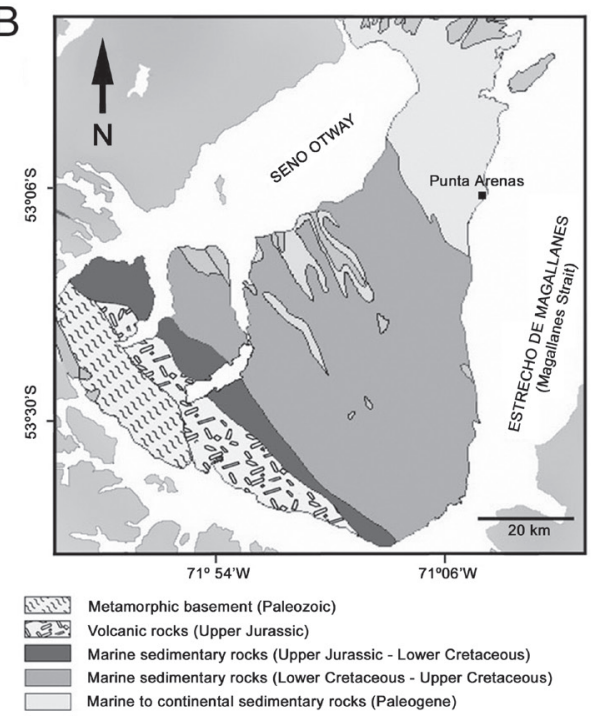

FIG. 1. A. Map of Brunswick Peninsula, southernmost Chile. The black arrow indicates the location of the Río de Las Minas study area. B. Schematic portrayal of the stratigraphic units exposed on the Brunswick Peninsula. 

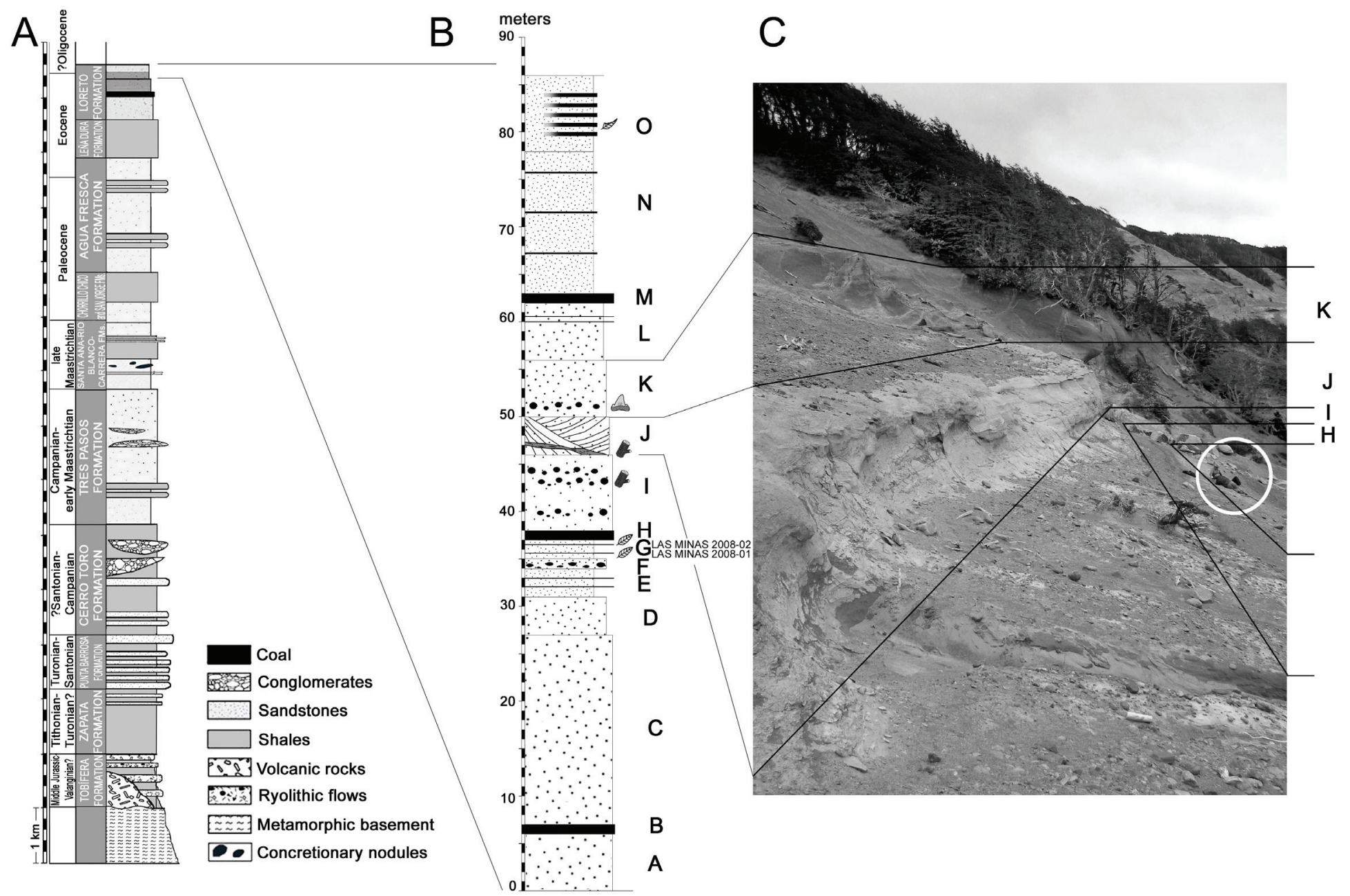

FIG. 2. A. Generalized stratigraphic column of the units exposed on the Brunswick Peninsula. The thickness of the units were taken from Katz (1963), Charrier and Lahsen (1969) and Fildani and Hassler (2005); B. Stratigraphic column based on the point ' $\mathrm{K}$ ' of Fasola (1969), in the Río de Las Minas, Punta Arenas, adding the observations of the measured section of this study (points $\mathrm{E}$ to $\mathrm{M}$ in the figure). Host beds of the fossiliferous material described here and the location of the samples dated by SHRIMP are indicated. For further details on each bed, see the text; C. General eastward view of the studied section at Río de Las Minas. The lines represent the same levels indicated on figure 2. White circle indicates human scale. 
Paleocene, as constrained by the age of the overlying Agua Fresca Formation.

Agua Fresca Formation (Hoffstetter et al., 1957): This up to $2,000 \mathrm{~m}$ thick formation consists of marine deposits exposed in the eastern part of the Brunswick Peninsula, along the Agua Fresca River. It is formed by sandstones and mudstones with abundant microfossils. The age of the formation is assigned to the Late Palaeocene-Early Eocene based on microfossils (Charrier and Lahsen, 1968, 1969).

Leña Dura Formation (Natland et al., 1974): This succession is about $640 \mathrm{~m}$ thick, consisting of grey, hard shales, with beds that include abundant concretions containing fossils. The age of the formation is assigned to the Late Eocene based on palynomorphs and invertebrate marine fossils (Fasola, 1969; Cookson and Cranwell, 1967).

Loreto Formation (Hoffstetter et al., 1957): This formation is about $800 \mathrm{~m}$ thick, being composed of well-sorted sandstones and including glauconitic and concretionary horizons with common intercalated beds containing fossil flora and several coal seams of variable thickness. It includes the Ciervos Member of Kniker (1949), assigned by this author to the Late Eocene based on microfossils. MartínezPardo et al. (1965) separated the basal part of the Loreto Formation (equivalent to the section measured at the Los Ciervos River by Fasola, 1969), raising it to formation status and assigning it to the Burdigalian based on taxonomic determinations of foraminifera referred to Candeina nitida D'Orbigny (=Antarcticella antarctica (Leckie and Webb); N. Malumián, personal communication, 2011), Globigerina falconensis Blow and Globigerinoides triloba inmmatura Le Roy. The latter genus was never found in the Magallanes Basin, and could in fact belong to Globigerinaspis, a taxon that dissappeared near the Eocene/Oligocene boundary (N. Malumián, personal communication, 2011). The age of the formation was reassigned by Fasola (1969) to the Oligocene based on palynomorphs, while Biddle et al. (1986) assigned the lower part of the Loreto Formation to the Rupelian-Chattian, correlating it with the Leña Dura Formation and the Zona Glauconítica unit (Hauser, 1964) exposed in Argentina. Later, Martínez-Pardo and Martínez (1989) reaffirmed his proposal of a Miocene age for the Ciervos Member, based on the presence of foraminifers of the genus Boltovskoyella, associated to Virgulinella severini (Cañón and Ernst); nevertheless, Boltovskoyella has been considered by Malumián and Jannou (2010) as an abundant, characteristic, and endemical taxon in the Atlantic transgression of the Magallanes Basin that occurred during the Eocene.

The fossil content of bivalves, gastropods (Fasola, 1969) and vertebrates (this study) and the presence of glauconite indicate that this unit was deposited in a shallow marine environment, although wood fragments and leaf imprints are also present.

\section{The Río de Las Minas section of the Loreto Formation}

A ca. $30 \mathrm{~m}$ thick stratigraphic section in the Río de Las Minas valley, which encompasses the beds containing vertebrate fossils and leaf imprints, was studied. It belongs to the upper part of the Loreto Formation according to the composite section of Fasola (1969), corresponding to point K of this author. According to Fasola's section, the strata that overlie the present studied profile are, from base to top, as follows (Fig. 2: B):

The beds underlying the studied section are exposed at the base of the cliff. Following Fasola (1969), from base to top these are:

A. $6 \mathrm{~m}$ of massive sandstones.

B. $0.8-1 \mathrm{~m}$ of coal.

C. $20 \mathrm{~m}$ of coarse, greenish, very friable sandstones with thin intercalated conglomerates, some strata containing calcareous concretionary nodules.

D. $4 \mathrm{~m}$ of massive sandstones with abundant concretionary nodules.

E. $3 \mathrm{~m}$ of fine sandstones with scarce and fine coal seams.

From base to top, the beds of the studied section are:

F. $1 \mathrm{~m}$ of massive sandstones with concretionary nodules at the base.

G. 2 m of alternating dark grey, poorly consolidated sandstones and fine coal seams that include abundant leaf imprints. Sample LAS MINAS 2008-01 for zircon dating was collected here. The base includes ca. $1 \mathrm{~m}$ of light grey, poorly consolidated sandstones with abundant leaf imprints. Sample LAS MINAS 200802 for zircon dating was collected in this interval. H. $1 \mathrm{~m}$ of coal.

I. $8 \mathrm{~m}$ of massive sandstones with abundant concretionary nodules.

J. $4 \mathrm{~m}$ of sandstones showing large-scale crossbedding with variable dip directions.

K. $6 \mathrm{~m}$ of massive sandstones with some concretionary beds. This unit also includes fine conglomerate 
lenses and abundant teeth of cartilaginous fishes, with less frequent bird bone fragments (Sallaberry et al., 2010).

L. $6 \mathrm{~m}$ of medium-grained, grey sandstones, with very fine coal intercalations.

M. $1 \mathrm{~m}$ of coal.

N. $15 \mathrm{~m}$ of massive sandstones with alternated, fine coal seams. At the base, the coal seams include fragmentary leaf imprints

Following Fasola (1969), and complemented with our own observations, the studied section is formed from top to base by (Fig. 2B and C):

O. $8 \mathrm{~m}$ of fine to medium sandstones including five prominent coal seams.

Our preliminary interpretation of the depositional environment is an estuary, based on the presence of shark teeth indicating a strong marine influence, coal seams representing stagnant marshes with abundant vegetation, and the large-scale cross-bedding of some sandstone units that is typical of Gilbert-type bayhead deltas or migrating barrier bars (e.g., Le Roux et al., 2010).

\section{Systematic paleontology}

\subsection{Fossil cartilaginous fishes}

\section{Chondrichthyes Huxley, 1880 \\ Elasmobranchii Bonaparte, 1838 \\ Subcohort Neoselachii Compagno, 1977 Order Lamniformes Berg, 1958 \\ Family Mitsukurinidae Jordan, 1898 Genus Striatolamia Glikman, 1964}

Type species: Otodus macrotus Agassiz, 1843; Eocene. Paris Basin, France.

\section{Striatolamia macrota (Agassiz, 1843)}

Fig. 3: A-C

Materials: SGO.PV.6513: (SGO.PV.=Institutional abbreviation for Área Paleontología, Museo Nacional de Historia Natural, Santiago): Seven anterior teeth; four lateral teeth; two postero-lateral teeth; one possible large lateral tooth.

Description: Teeth with high and slender crown, less sigmoidal in profile than Odontaspis, and with complete cutting edges that fade towards the base. The anterior teeth highly resemble Odontaspis, but differ in the presence of rough, well-marked striations that extend from the base and fade close to the top of the crown over the lingual face. Lateral cusplets are small and recurved to the crown. The root shows an inverted ' $V$ ' shape, with separate branches. Lateral teeth have broader crowns, with soft striations on the lingual face. The cusplets are broad and short, with rounded tops, some having a pectinated aspect. The root is robust and the branches are massive and not separated like those seen in anterior teeth.

Comments and age: Cappetta (1987) indicates that during its stratigraphic history, the genus Striatolamia has shown a clear tendency to increase the size of its teeth, with a broadening of the main cusplet. This is particularly evident in later fossils of the species S. macrota. This author also points out for the lateral teeth of this species, that the lateral cusplets underwent a marked widening, becoming broad, short and rounded (pectinated aspect). They also display a fading of the striations on the lingual face, these becoming shorter, fading or even disappearing altogether. The species $S$. macrota has already been reported from the Loreto Formation by Suárez and Marquardt (2003) as a taxon with good chronostratigraphic value that indicates an Eocene age. The newly recovered material shows morphologies that resemble later members of the species. S. macrota has been reported in the Early Palaeocene-Late Eocene of the ex-U.S.S.R., North America, and the north and west of Africa (Cappetta, 1987). It is also known in the Eocene of Seymour Island, Antarctica (Long, 1992; Kriwet, 2005). Teeth of S. macrota with broad cusplets have furthermore been reported from the Middle Eocene of North Carolina (Case and Borodin, 2000) and the extreme south of South America (Arratia and Cione, 1996).

\section{Genus Anomotodon Arambourg, 1952}

Type species: Anomotodon plicatus Arambourg, 1952. Maastrichtian, Morocco.

\section{Anomotodon sp.}

Fig. 3: D

Materials: SGO.PV.6514: A single anterior tooth. Description: Small tooth with high and slender crown. The enamel extends laterally, having smooth cutting edges. No cusplets are noted. The root branches are thin, extended in antero-posterior direction, and widely separated.

Comments and age: The shape of the tooth from Punta Arenas is highly similar to the species $A$. novus. 


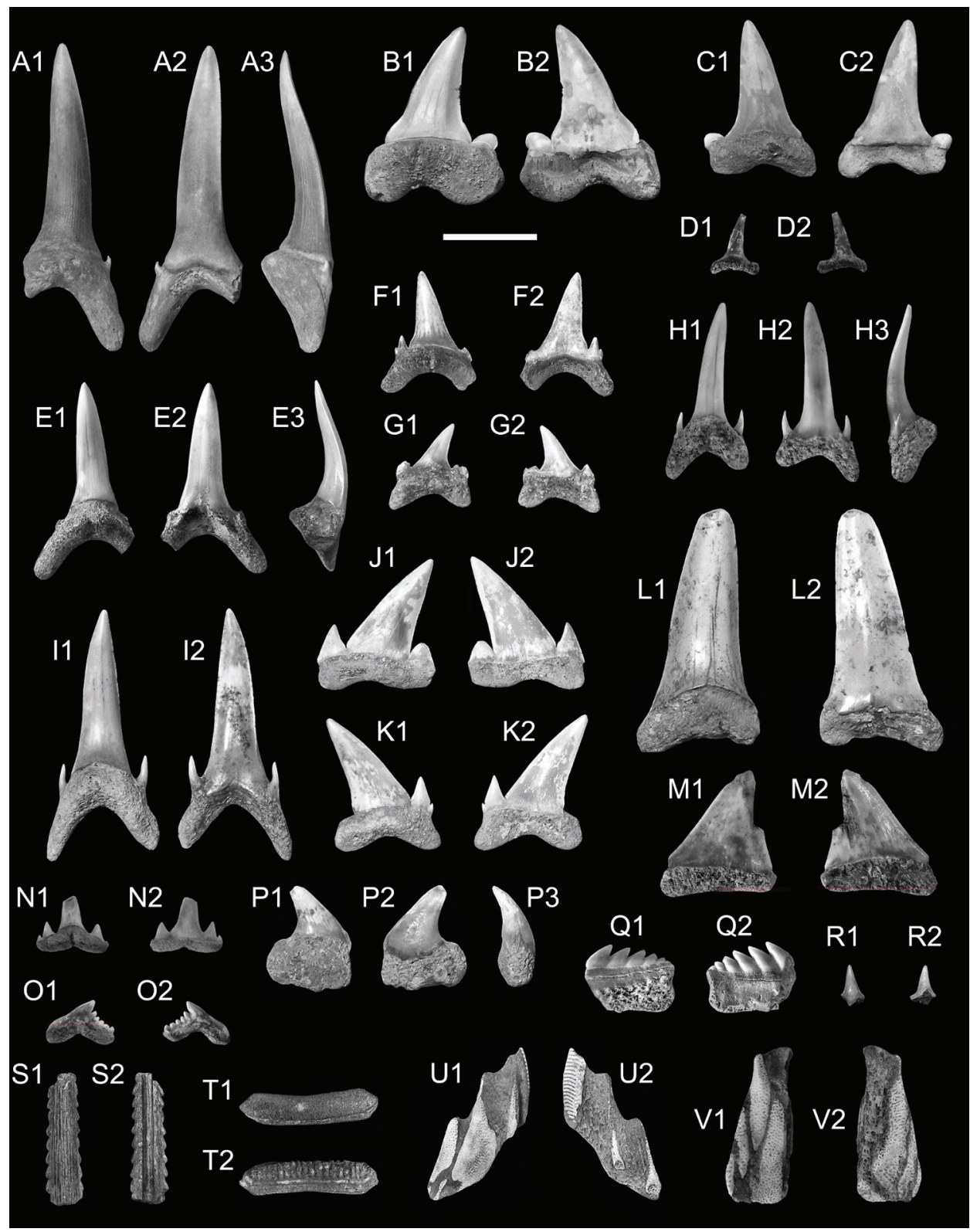

FIG. 3. SGO.PV.6513: Striatolamia macrota (Agassiz, 1843). A1. Anterior tooth in lingual view; A2. labial view; B1, C1. posterolateral teeth in lingual views; B2, C2. labial views. SGO.PV.6514: Anomotodon sp. D1. Anterior tooth in lingual view; D2. labial view. SGO.PV.6510: Carcharias aff. 'hopei' (Agassiz). E1. Anterior tooth in lingual view; E2. labial view; E3. profile view; F1, G1. lateral teeth in lingual view; F2, G2. labial views, SGO.PV.6511: Odontaspis sp. H1. Anterior tooth in lingual view; H2. labial view; H3. profile view. SGO.PV.6512: Carcharoides catticus (Philippi, 1846). I1. Upper anterior tooth in lingual view; I2.labial view; J1, K1. lateral teeth in lingual views; J2, K2. labial views. SGO.PV.6515: Macrorhizodus (Isurus) praecursor (Leriche, 1905). L1. Anterior lower tooth in lingual view; L2. labial view; M1. lateral upper tooth in lingual view; M2. labial view. SGO.PV.6517: Abdounia sp; N1. Anterior tooth in lingual view; N2. labial view. SGO.PV.6516: Galeorhinus sp. O1. Lateral tooth in lingual view; O2. labial view. SGO.PV.6518: Hexanchidae indet. M1. Upper anterior tooth in lingual view; M2. labial view; M3. profile view. SGO.PV.6519: Hexanchus sp. N1. Lateral lower tooth in lingual view; N2. labial view. SGO.PV.6520: Squatina sp. R1. Antero-lateral tooth; R2. labial view; P. lingual view. SGO.PV.6521: Myliobatoidea indet. S1.Distal fragments of caudal spine in dorsal view; S2. ventral view. SGO.PV.6522: Myliobatis sp. T1. Medial tooth in occlusal view; T2. basal view. SGO.PV.6524: Ischyodus dolloi Leriche, 1902. U1.Left mandibular plate in occlussal view; U2. basal view; V1. right palatine in occlussal view; V2. basal view. Scale bar=1 cm. 
Nevertheless, the absence of more dental pieces prevents its identification as the same species. The genus is known since the Lower Cretaceous to the Early Miocene in Europe, North America, north and west Africa and Japan. Eocene reports come from Belgium, the ex-U.S.S.R. and England (Cappetta, 1987), as well as Seymour Island, Antarctica (Long, 1992; Kriwet, 2005) where the species $A$. multidenticulatus was identified.

\section{Family Odontaspididae Müller and Henle, 1839 Genus Carcharias Rafinesque, 1810}

Type species: Synodontaspis hopei (Agassiz, 1843), Eocene. England, France, Belgium and Morocco.

\section{Carcharias aff. 'hopei' (Agassiz)} Fig. 3: E-G

Materials: SGO.PV.6510: Four anterior teeth, lacking lateral cusplets in most cases; six lateral teeth, with partial cusplets; two intermediate teeth, with partially preserved cusplets; two complete latero-posterior teeth; one symphysial tooth, lacking cusplets.

Description: Anterior teeth with high cusp, thin and slender, with a sigmoidal profile and ' $V$ ' shaped root. The crown has complete cutting edges, fine striations on its lingual face and enamel rifts. The labial face has enamel with soft folds close to the root. Two lateral cusplets are present on each side, but they have been lost in most cases due to erosive processes. The root has two separate branches and shows a bulk with a medial nutritious groove. Intermediate teeth show a lower crown but a very similar root to anterior ones. The lateral cusplets are present in most cases, being robust and joined to the crown, having a continuous enamel surface between the cusp and the lateral cusplets on the labial face. Posterior teeth are similar, but with a crown recurved backwards. The symphysial tooth shows a bulky root, high and broad in the labial-lingual direction. Despite the fact that only one root branch is preserved, they are not broadly separated.

Comments and age: The recovered teeth from Punta Arenas are very similar to those figured by Cappetta and Nolf (2005, p. 260) referred to as Carcharias $\mathrm{sp}$. These authors indicate that their tooth set has affinities to the recent species C. taurus, being morphologically more similar to the latter than the fossil C. acutissima. They also indicate that their materials probably share the systematic attributes of C. hopei, but specific identification is discarded because they consider that the species hopei is still not clearly described. Following this, the identification of the tooth set from Punta Arenas is included in the genus Carcharias, noting its high similarity to the 'hopei' taxon, but refraining from a more specific identification.

Kent (1994) indicates that the genus Carcharias has a cosmopolitan distribution in the CampanianRecent. Regionally, fossil Carcharias species are reported from the Cenozoic of Ecuador, Peru and Chile (Cione et al., 2007). The presence of the genus Carcharias in Chile has been documented since the Campanian-Maastrichtian, from the Quiriquina Formation and equivalent units (Suárez et al., 2003, Table 1; Muñoz-Ramírez et al., 2007). In addition, it was previously reported from the Eocene of the Loreto Formation (Suárez and Marquardt, 2003), and is also present in the Early Miocene of the Navidad Formation (Suárez et al., 2006), at least one species having been identified as C. cuspidata Agassiz. The youngest report of the genus Carcharias in Chile belongs to Late Miocene-Early Pliocene deposits of the Bahía Inglesa Formation (Suárez et al., 2004). Concerning the species C. hopei, it is known from the Early Eocene of England, and the Eocene of the French-Belgian Basin and Morocco (Cappetta, 1987). Ward (1988) also indicates its occurrence in the Late Paleocene of England, the Paleocene, as well as the Middle Eocene of Belgium and the Eocene of Maryland.

\section{Genus Odontaspis Agassiz, 1838}

Type species: Squalus ferox (Risso, 1810). Recent, warm waters of the northeastern Atlantic, Pacific Indian, and Mediterranean Oceans.

\section{Odontaspis sp.}

Fig. 3: H

Materials: SGO.PV.6511: Four antero-lateral teeth, one of them with cusplets.

Description: High crown, slender and sharp, thinner and sharper than those seen in the genus Carcharias, and with a sigmoidal shape in profile. It shows soft striations at the base of the lingual face and some grooves, while the labial face is completely smooth. The labial face is flattened at the top and, in cross 
TABLE 1. SYNTHESIS OF THE KNOWN STRATIGRAPHIC DISTRIBUTION OF THE MOST EXCLUSIVE TAXA OF FOSSIL CARTILAGINOUS FISHES (CHONDRICHTHYES) RECOVERED AT PUNTA ARENAS, SOUTHERNMOST CHILE. FOR DETAILS, SEE THE TEXT FOR EACH TAXON.

\begin{tabular}{|c|c|c|c|c|c|c|c|c|c|c|c|c|}
\hline $\begin{array}{c}\text { Upper } \\
\text { Cretaceous }\end{array}$ & \multicolumn{3}{|c|}{ Paleocene } & \multicolumn{4}{|c|}{ Eocene } & \multicolumn{2}{|c|}{ Oligocene } & \multicolumn{3}{|c|}{ Miocene } \\
\hline 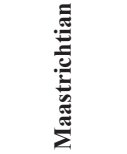 & 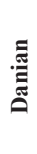 & 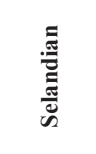 & 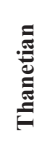 & 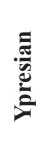 & ل & & 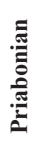 & 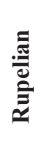 & & 䔅 & 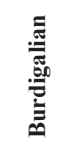 & 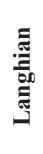 \\
\hline
\end{tabular}

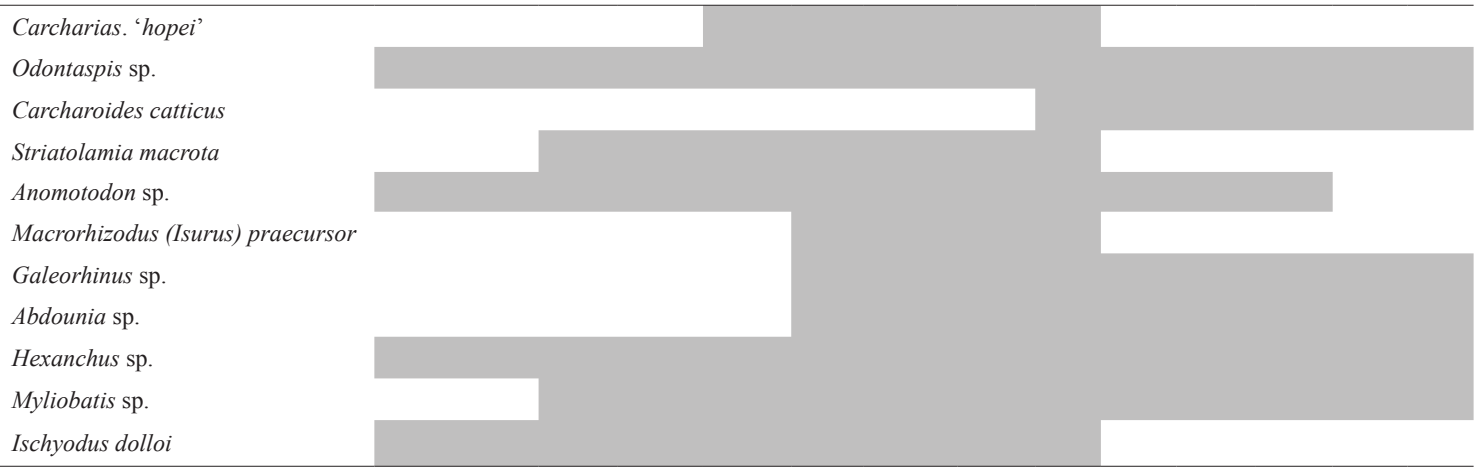

section displays a rounded shape near the base. The cutting edges extend from the top, but fade before reaching the base. The contact between the crown and the root has a neck, causing the enamel to slightly overhang the root.

Comments and age: A typical character of the genus Odontaspis is the incomplete cutting edges that do not reach the base of the cusp (Cappetta, 1987; Kent, 1994). This allows their distinction from other odontaspidids such as Carcharias, where the cutting edges are complete. Teeth of the genus Carcharias commonly found in the Loreto Formation allow their comparison with those of SGO.PV.6511, which highlights the different cutting edges. Due to the incomplete preservation of the teeth and the lack of more complete samples, specific identification was not attempted.

Odontaspis is known since the Campanian to Recent in Europe, northern and western Africa, North America (Cappetta, 1987) and the south of South America, (Arratia and Cione, 1996). In Chile, fossil specimens are mentioned in the Eocene of Lebu (Oliver-Schneider, 1936), referred to as the species O. elegans (Agassiz). Furthermore, the genus is reported in the Late Miocene-Early Pliocene Bahía Inglesa Formation (Suárez et al., 2004). Finally, the species
O. ferox Risso was reported in the Early Miocene of the Navidad Formation (Suárez et al., 2006).

\section{Genus Carcharoides Ameghino, 1901}

Type material: Carcharoides catticus (Philippi, 1846). 'Tertiary' of Europe.

\section{Carcharoides catticus (Philippi, 1846)} Fig. 3: I-K

Materials: SGO.PV.6512: Two complete anterior teeth; four upper lateral teeth, only one complete; three teeth preserving only one lateral cusplet; two upper posterior teeth.

Description: Anterior teeth with high, straight and slender crown, becoming recurved backwards and broader in the posterior teeth. The lingual face is slightly convex, while the labial face is very flat, both faces having soft enamel with no striations. In profile, some teeth show a slightly sigmoidal aspect. All teeth have two cusplets with soft and flat faces, those of the anterior teeth being very thin and sharp, while those of the lateral and posterior teeth are broad and triangular in shape. Two lateral teeth show incipient secondary cusplets. The cutting 
edge is continuous in all cases, fading near the base of the cusp. The root has short separated branches with a medial constriction at the base, and lingually displays a single nutritious groove in a central position. In most of the teeth, this groove is not evident, due the erosion suffered by the root.

Comments and age: The genus Carcharoides includes only two known species: C. totuserratus Ameghino, 1901 and C. catticus (Philippi, 1846). The first species was reported exclusively from the Southern Hemisphere, particularly in the Late Oligocene of Australia (Chapman, 1913; Fitzgerald, 2004), the Early Miocene of Argentina (Cione, 1978; Cione and Expósito, 1980) and the Early Miocene of Chile (Suárez et al., 2006). The second species, C. catticus, can be diagnosed by anterior odontaspidid-like teeth and lamnoid lateral teeth, the latter with a triangular cusp and one triangular cusplet on each side, bent lingually (Cappetta, 1987), and having a smooth cutting edge that frequently does not reach the base. These teeth have compressed cusps, while the roots branches are short and well separated. The species has been reported from the Oligocene-Miocene of Europe and west Africa (Cappetta, 1987). Finally, Werner (1989) referred some dubious materials from the Cenomanian of Egypt to Carcharoides.

\section{Family Lamnidae (Müller and Henle, 1838a) Genus Macrorhizodus Glikman, 1964}

Type species: Isurus praecursor (Leriche, 1905). Middle Eocene, Belgium.

\section{Macrorhizodus (Isurus) praecursor (Leriche, 1905)}

Fig. 3: L, M

Materials: SGO.PV.6515: One anterior lower tooth; one lateral upper tooth.

Description: High, slender and triangular crown that becomes broader towards the base, being labio-lingually compressed. The labial face is flat, with soft enamel and smooth folds near the root. The lingual face is convex and the enamel shows some rifts.

Comments and age: The species Macrorhizodus praecursor (=Isurus praecursor) was previously reported from Eocene deposits in Belgium, Syria, Egypt, Nigeria, Togo, Guinea Bissau and England (Cappetta, 1987). It was also reported from the Middle-Late Eocene of Chesapeake Bay, U.S. (Kent,
1994), and the Middle-Late Eocene of Seymour Island, Antarctica (Cione and Reguero, 1994).

\section{Order Carcharhiniformes Compagno 1973 Family Carcharhinidae Jordan \& Evermann, 1896}

Type species: Eugaleus beaugei Arambourg, 1935. Lower Eocene, Morocco.

\section{Genus Abdounia Cappetta, 1980a Abdounia sp.}

Fig. 3: N

Materials: SGO.PV.6517: A single tooth.

Description: Small tooth with moderately high crown and two lateral cusplets with triangular shape on each side. The labial face is flat and the lingual face has a soft convexity. The top of the crown and one of the distal cusplets are absent. The cusplets are slightly recurved to the crown. The enamel is smooth and continuous from the main cusp to the lateral cusplets. Cutting edges are smooth and complete over all of the crown. The root is robust, with separated branches and one medial, well-marked groove.

Comments and age: The genus can be diagnosed by the small-sized teeth, with a relatively triangular cusp, broader near the base, having a flat labial face and a slightly convex lingual face, displaying one or more lateral cusplets and a crown that does not overhang the labial face of the root. This latter has branches transversely extended, with a well-marked, deep groove (Cappetta, 1987), typical of carcharhinid sharks. The genus is known in the Early-to-Late Eocene of Europe, North America, North and West Africa (Cappetta, 1987) and in the Early Eocene of India (Rana et al., 2004).

\section{Family Triakidae Gray, 1851 \\ Genus Galeorhinus de Blainville, 1816}

Type species: Squalus galeus Linnaeus, 1758. Recent, all seas.

\section{Galeorhinus sp.}

Fig. 3: $\mathrm{O}$

Materials: SGO.PV.6516: One complete tooth.

Description: Small tooth with broad, low crown and broad root. The crown has a main cusp, recurved backwards, with a smooth anterior cutting edge and 
five cusplets in the distal portion. The crown extends over the root onto the labial face. The root has separate branches and a well-developed medial groove. Comments and age: Its known biocron ranges from the Eocene to Recent. Eocene reports come from Egypt, the United States (Cappetta, 1987), Belgium (Nolf, 1988) and India (Rana et al., 2004). The genus is also reported from the Eocene of Seymour Island (Kriwet, 2005). In Chile, it was previously reported from Campanian-Maastrichtian beds at Talcahuano Bay (Muñoz et al., 2007) and from the Neogene of the Bahía Inglesa Formation (Long, 1993).

\section{Order Hexanchiformes de Buen, 1926 \\ Suborder Hexanchoidei Garman, 1913 \\ Family Hexanchidae Gray, 1851 \\ Hexanchidae gen. et sp. indet.}

Fig. 3: P

Materials: SGO.PV.6518: Single upper anterior tooth. Description: Acrocone (main cusp) robust, recurved backwards and also lingually, with complete anterior cutting edge, smoothly serrated, and no cutting edge along posterior margin. On lingual face, smooth grooves are noted at the base and the enamel overhangs the root.

Comments and age: Apparently, the tooth has no secondary cusplets. Nevertheless, the preservation of the root is poor, and it is difficult to establish whether there was a loss of secondary cusplets by erosive processes. Nevertheless, the presence of smooth serrations on the anterior cutting edge is common in teeth of hexanchid sharks and some squaliformes, but the absence of a posterior cutting edge is unusual. Cappetta (1987) indicates that in larger individuals of the genus Notorhynchus, this posterior cutting edge often disappears close to the base. The poor preservation and lack of additional teeth from this locality do not allow an accurate generic identification.

\section{Genus Hexanchus Rafinesque, 1810}

Type species: Squalus griseus Bonaterre, 1788. Recent, all seas.

\section{Hexanchus sp.}

Fig. 3: Q

Materials: SGO.PV.6519: Single lateral lower tooth. Description: Incomplete tooth lacking the main cusp (acrocone). Its general shape is expanded in the antero-posterior sense and compressed in the labial-lingual sense. The crown preserves six cusplets (accessory cones), these being recurved backwards and decreasing in size towards the posterior portion. The root has a rectangular shape with a rift near its contact with the crown.

Comments and age: The genus is known since the Early Jurassic to Recent (Cappetta, 1987), with a cosmopolitan distribution. Regionally, Eocene Hexanchus has been described from Seymour Island, Antarctica (Cione and Reguero, 1994).

\section{Order Squatiniformes de Buen, 1926 Family Squatinidae Bonaparte, 1838 Genus Squatina Duméril, 1806}

Type species: Squalus squatina Linnaeus, 1758. Recent, all tropical seas.

\section{Squatina sp. \\ Fig. 3: R}

Materials: SGO.PV.6520: One antero-lateral tooth. Description: Small tooth with relatively high and sharp crown. This is slightly recurved backwards and has a ventral extension over the root. The lateral flanks are partially preserved, but in all species it extends for almost the whole length of the tooth, having a continuous cutting edge. The root is absent, nevertheless. All the species have two well-separated branches and a lingual bulk.

Comments and age: The genus was previously reported since the Oxfordian to Recent (Cappetta, 1987), and has a cosmopolitan distribution. Regionally, it was previously reported from Upper Cretaceous beds in central Chile (Suárez et al., 2003) and from probable Paleocene beds in south-central Chile (Muñoz-Ramírez et al., 2008). Furthermore, it was reported from the Eocene of Seymour Island, Antarctica (Welton and Zinsmeister, 1980).

Superorder Bathomorphi Cappetta, 1980b

Order Myliobatiformes Compagno, 1973

Superfamily Myliobatoidea Compagno, 1973 Myliobatoidea indet. Fig. 3: $\mathrm{S}$

Materials: SGO.PV.6521: Five fragments of caudal spines.

Description: Elongated spines, with broad proximal portion and thinner distal end. The lateral flanks are 
serrated, fading close to the insertion area (proximal end). They differ by the presence of profuse striations on the dorsal surface and a ventral keel in the distal portion, while other samples have soft striations and a shallow ventral groove at the distal end. The fragmentary condition of the material prevents the observation of the complete morphology of the caudal spines. The two different striated fragments are a proximal and distal end respectively, probably belonging to the same taxon and indicating the general shape of this morphotype.

Comments and age: Myliobatoids are known since the Campanian to Recent, with a cosmopolitan distribution (Cappetta, 1987). Also, they have been recognized on Seymour Island, Antarctica (Kriwet, 2005).

\section{Family Myliobatidae Müller and Henle, 1837 Genus Myliobatis Cuvier, 1817}

Type species: Raja aquila Linnaeus, 1758. Recent, all warm seas.

\section{Myliobatis sp.}

Fig. 3: T

Materials: SGO.PV.6522: Four medial teeth.

Description: Teeth broader than length, with hexagonal contour. The crown is flat and quite convex, being displaced anteriorly with respect to the root. The latter shows multiple parallel grooves disposed in an antero-posterior direction.

Comments and age: The recovered materials show a general small size for all the individuals. Cappetta (1987) indicates that the numerous myliobatid species diversified since the Eocene possess teeth with a thick and granular enameloid, this also being noted in the Chilean material.

The genus Myliobatis is known since the Early Paleocene to Recent, with a cosmopolitan distribution (Cappetta, 1987).

\section{Subterbranchialia Zangerl, 1979 Holocephali Bonaparte, 1832 \\ Order Chimaeriformes Obruchev, 1953 Suborder Chimaeroidei Patterson, 1965 \\ Family Callorhynchidae Garman, 1901 Genus Ischyodus Egerton, 1843}

Type species: Ischyodus dolloi Leriche, 1902. Paleocene, Belgium.

\section{Ischyodus dolloi Leriche, 1902}

Fig. 3: U, V

Materials: SGO.PV.6524: Two left mandibular plates, one right palatine and one left palatine.

Description: SGO.PV.6524: Massive mandibular plate, rhomboidal in shape, with two embayments along the occlusal margin. The symphysial tritor is laminated and located in the anterior end of the symphysial margin. The larger medial tritor is broad near the basal end and thinner close to the occlusal end. The outer posterior tritor is elongated over the occlusal margin. The smaller tritors are the anterior inner tritor, the anterior outer tritor and the accessory median tritor. The palatine plates have a larger size and more robust tritors. The apical margins show differences in wearing and the basal margins have a distinct, broad shape.

Comments and age:The species $I$. dolloi has been reported in the Late Cretaceous (Stahl and Chatterjee, 2003) and from the Eocene of Seymour Island, Antarctica (Ward and Grande, 1991). The material from Punta Arenas is very similar to that figured by these authors (p. 329, Fig. 6b), in particular the Chilean mandibular plates have an occlusal end with comparatively more wear, and part of the basal end being absent. Comparing both Chilean mandibular plates, the configuration and relative position of all the tritors are broadly similar; nevertheless, they appear to be slightly different in that the median and anterior inner tritors show a distinct development. In addition, the size of the plate is different and one apical margin is less sharp, suggesting that this belongs to a younger individual. Ward and Grande (1991) indicate that the growing of dental plates of Ischyodus occurs on the basal surface, giving the plate a basal margin narrower than the apical, which causes a change in the general shape and a rotation of the plate in different stages of the ontogeny, becoming broader and less slender (Ward and Grande, 1991; Fig. 3). The recovered mandibular plates from Punta Arenas preserve the configuration of the tritors seen in I. dolloi, but the differences between both plates can be interpreted as resulting from different ontogenetic stages.

The type material of I. dolloi is reported from the Paleocene of Belgium and France (Leriche, 1902). The species is also known from the Eocene of England (Ward, 1973), Paleocene of North Dakota (Cvancara and Hoganson, 1993), the Paleocene-Eocene of Russia (Popov 1996) and the Late Eocene of Seymour Island, Antarctica (Ward and Grande, 1991). The earliest 
report comes also from this locality, where Stahl and Chaterjee (2003) identified the species in lower Maastrichtian deposits, this being its oldest known record and suggesting that its origin was in southern high latitudes. Ischyodus cf. dolloi is also reported from the Neogene of Australia (Fitzgerald, 2004).

\subsection{Paleobotany}

Macroflora are especially abundant in level H (Fig. 2B) of the studied section, but the hosting beds are formed by poorly consolidated sediments, making it difficult to obtain complete samples. Identified leaf imprints indicate the presence of Pteridophytes of the genera Asplenium sp. and Pteris sp. Additionally, pinophytes of the genus Podocarpus were recognized. The angiosperms are the most abundant assemblage, including Nothofagus lanceolata Dusén; N. simplicidens Dusén; $N$. variabilis Dusén; $N$. cf. alessandri Espinosa (=Betuliphyllum patagonica Dusén); N. subferruginea (Dusén); Hydrangea sp. and Phyllites spp. Although wood remains seem to be scarce, samples collected from coal seams near the base of the measured section were identified as Nothofagoxylon scalariforme Gothan, which display well-marked growth rings. A different taxon referred to Araucariaceae cf. Araucarioxylon Kraus was recognized from the same strata, being very similar to previously reported material from the northern outcrops of the Loreto Formation, referred by Terada et al. (2006) to Araucarioxylon pichasquense Torres and Rallo.

Three samples considered for palynologic analysis were collected from level E, H and J of the succes- sion, although level E did not show any evidence of palynomorphs (Torres et al., 2008). Level H includes spores of Dicellasporites sp., Multicellaesporites sp., trilete spores of pteridophytes, mainly Cyathidites spp. and Laevigatosporites ovatus Wilson and Webster. Gymnosperms are represented by Podocarpidites otagoensis Couper while angiosperms include $R e$ titricolpites sp., Tricolpites sp. and Liliacidites sp. Finally, Caryophylaceae are represented by Polyporina sp. Level J includes palynomorphs and cuticles, stromes of Callimothallus, spores of Dicellaesporites sp., Multicellaesporites sp., and Granatisporites sp. Additionally, it includes pteridophytes such as Cyathidites minor Couper, Cyathidites australis Couper and Laevigatosporites ovatus Wilson and Webster. Gymnosperms are represented by Podocarpidites otagoensis Couper and Angiosperms by Nothofagidites cincta Cookson, Nothofagidites cranwellae Couper and psilated Tricolpites.

\section{SHRIMP U-Pb dating of detrital zircons}

Detrital zircons from two fine-grained sandstone beds from the Río de Las Minas section were separated for dating, with the main purpose of contributing to the age determination of the succession. The position of the samples in the stratigraphic column is shown in figure $2 \mathrm{~B}$.

\subsection{Methodology}

The zircon concentrates were prepared at the Departamento de Geología, Universidad de Chile.
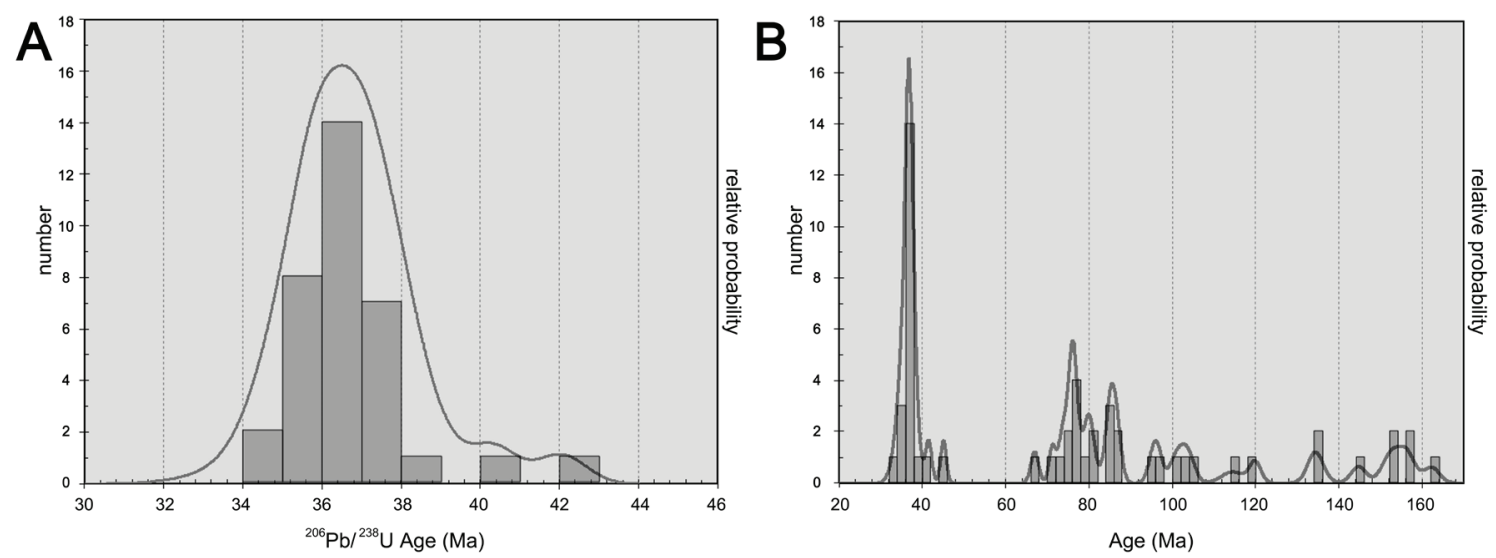

Fig. 4. A. Age versus probability diagram for the younger zircons from sample Las Minas 2008-01; B. Age versus probability diagram for the Mesozoic and Cenozoic zircons from sample Las Minas 2008-02. 
The U-Pb-Th SHRIMP ages determined during this investigation were obtained using SHRIMP I, II and RG at the Research School of Earth Sciences, Australian National University, Canberra. The measurement techniques employed followed those of Williams (1998). FC1 was used as the standard throughout, and the data were processed using the SQUID Excel Macro of Ludwig (2001). Thirty-eight (sample Las Minas 2008-01) and 60 (sample Las Minas 2008-02) grains were analyzed, in each case with four-scan data. The respective results are indicated as age probability plots for individual samples shown in Fig. 4, A and B. The Geological Time Scale used throughout the text is that of Gradstein et al. (2008).

\subsection{Results}

All analysed zircon grains are igneous, as revealed by typical zoning in CL images (not shown). Thirtyeight zircon grains were analysed from sample Las Minas 2008-01,32 of which form a very well-defined peak at $36.48 \pm 0.47 \mathrm{Ma}(\mathrm{MSWD}=1.5)$. An additional small grouping of 3 grains ( 74 to $77 \mathrm{Ma}$ ), and single dates at $42 \mathrm{Ma}$ and $619 \mathrm{Ma}$ are also present.

Sixty zircon grains from the more complex Las Minas 2008-02 sample were analysed. A dominant peak of 19 grains at $36.73 \pm 0.50 \mathrm{Ma}(\mathrm{MSWD}=0.65)$ groups the youngest grains. Two somewhat older grains (42 and $45 \mathrm{Ma}$ ), a relevant scatter of 32 grains in the age interval 67 to $162 \mathrm{Ma}$, and isolated grains with Paleozoic (3 grains), Proterozoic (3 grains) and Archean (1 grain) ages complete the age spectrum obtained. The analytical data for each sample are included in Appendices I and II, respectively.

\section{Discussion}

\subsection{Fossil cartilaginous fishes}

Few occurrences of Paleogene elasmobranchs are known in Chile. Muñoz-Ramírez et al. (2008) reported probable Palaeocene chondrichthyan fauna from the coast of the Biobío Region in south-central Chile. In the same region, at Lebu, an uncertain and not figured tooth referred to Odontaspis elegans was reported by Oliver-Schneider (1936) from Eocene beds. Eocene myliobatid tooth plates were also mentioned by Suárez and Marquardt (2003) from the Valparaíso Region of central Chile. The southernmost known Eocene elasmobranchs were recovered from Punta Arenas in the Magallanes Region, where Suárez and
Marquardt (2003) identified the presence of three elasmobranch families that include one genus with good chronostratigraphic resolution, allowing these authors to propose an undifferentiated Eocene age for the host beds.

Previous studies have cited the presence of elasmobranch fishes in the Brunswick Peninsula. Tavera (1946) described a single tooth identified as Lamna? sp. (Fig. 130, plate IX). The material was poorly presented and no indication about its final repository was provided, nevertheless, it probably belongs to an anterior tooth of S. macrota, associated with abundant Eocene invertebrate fauna. Fasola (1969) also includes material of elasmobranchs identified as Oxyrhina sp. (nomen vanum), but this was not figured or described (only his unpublished doctoral thesis includes a picture of the tooth, which probably is a lateral tooth of Striatolamia macrota). The most recent publication dealing with elasmobranchs from the Loreto Formation is that of Suárez and Marquardt (2003) indicating the presence of the species S. macrota (Agassiz), Carcharias sp., teeth of myliobatids, and fragments of dorsal spines of indeterminate holocephalian fishes. The presence of all these taxa is confirmed by the present study.

The recovered materials studied by us include two taxa known since the Eocene (Galeorhinus and Abdounia sp.) and two taxa that remain unreported after the Eocene (S. macrota, and I. dolloi). The presence of $C$. catticus suggests an age close to the Eocene/Oligocene boundary, while the remaining taxa do not provide a finer resolution. This new information allows us to constrain the host beds as Eocene, confirming the previous proposal of Suárez and Marquardt (2003), but adding more precision on the stratigraphic position of this unit.

\subsection{Paleoecology}

Considering the newly collected materials and comparing them with Eocene elasmobranch assemblages worldwide (Table 2), closer faunal affinities are observed with the assemblages from the European basins, where almost all of the genera and species are known from the Eocene. Also, a clear affinity is observed with the elasmobranch diversity reported from the Atlantic coast of North America, with similarities in ten of the twelve taxa. When they are compared with the Eocene north African elasmobranch fauna, eight of the twelve taxa are similar. The same is the case with the elasmobranch 
TABLE 2: GEOGRAPHIC DISTRIBUTION OF THE STUDIED FOSSIL TAXA OF CARTILAGINOUS FISHES (CHONDRICHTHYES) IN THE MAIN MARINE PROVINCES DURING THE EOCENE. FOR DETAILS, SEE THE TEXT FOR EACH TAXON.

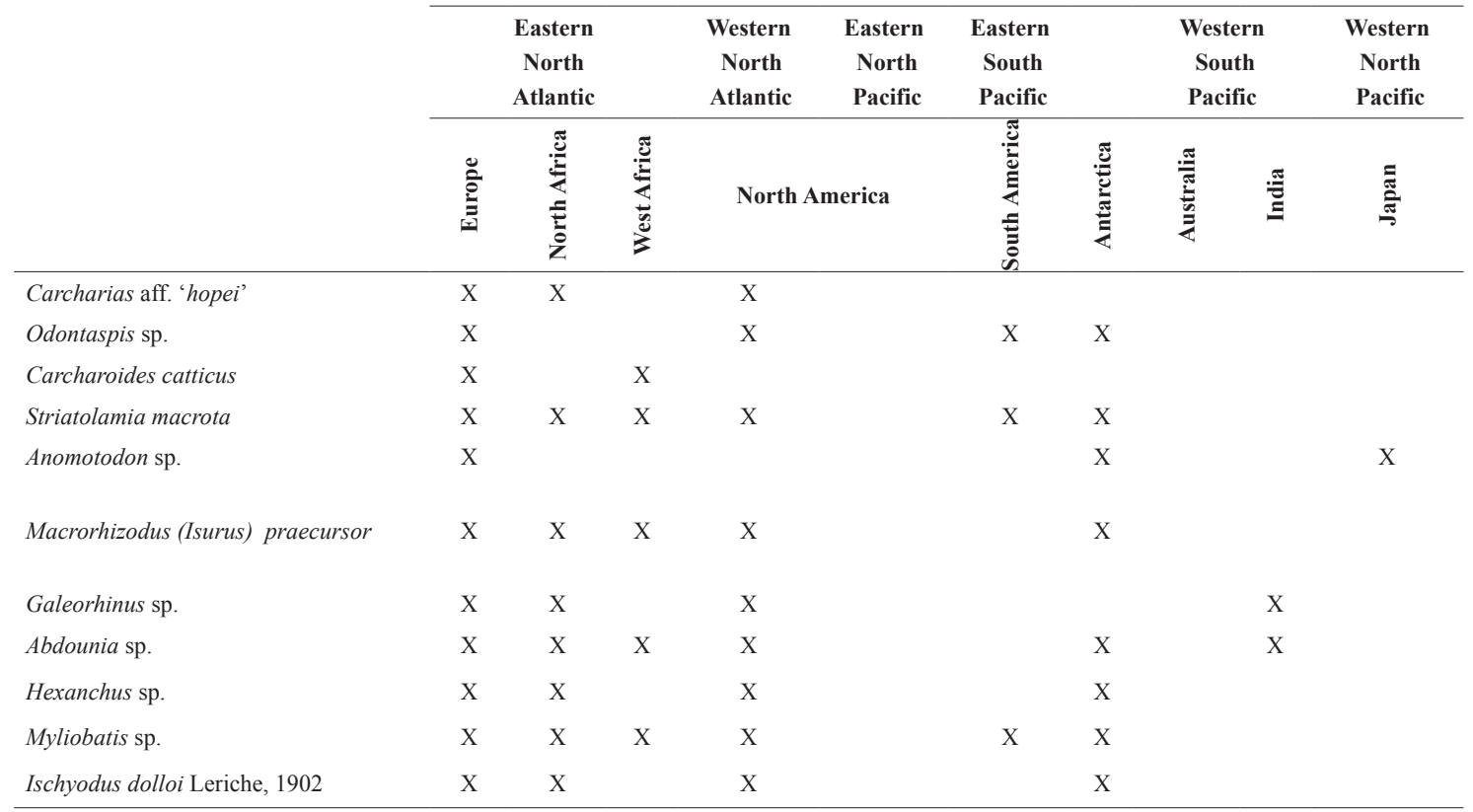

diversity in the Eocene of Antarctica. However, common elements with Indo-Pacific records are scarce. This suggests a closer connection between Tethyan elasmobranch fauna and those assemblages from Seymour Island and southernmost Chile, instead of a direct connection with elasmobranch faunas from the Pacific Ocean. The situation seems to be consistent with the conditions of oceanic currents before the Early Oligocene, before the opening of the Drake Passage and the Australian-Antarctic Gulf caused important variations in the seaways in the circum-Antarctic region (Lawver and Gahagan, 2003) and consequently, important climatic changes.

\subsection{Paleoclimate and paleoenvironment}

An estimation of climatic conditions can be obtained by evaluating the habitat of the extant elasmobranchs present in the Eocene of southernmost Chile. Extant hexanchid sharks inhabit cold temperate to tropical seas (Compagno, 1984), while odontaspidids are tropical to warm-temperate, inshore to offshore, littoral and deepwater sharks. Additionally, squatinids have a broad distribution in cool temperate to tropical waters (Compagno,
2001). Triakids such as Galeorhinus as well as myliobatids are found in warm-temperate waters. This indicates a range of temperate waters for the marine environmental conditions during deposition of the sediments in the studied section of the Loreto Formation. Additionally, comparison of the studied taxa with the environmental conditions of their closest extant species, provides information about the depth in which their host beds were deposited. The most frequent sharks recovered are the odontaspidids, represented mainly by Carcharias aff. 'hopei' and scarce teeth of Odontaspis sp. Odontaspidids are frequent in depths ranging 15 to 25 $\mathrm{m}$ (Compagno, 2001). Other frequent remains are myliobatids, represented by the genus Myliobatis. The latter is known in shallow depths up to $20 \mathrm{~m}$. On the other hand, inhabitants of deeper water are scarcely represented. Such is the case of Squatina sp. that dwells from the surf line to a depth of several hundred meters, being represented in the recovered material by a single fragmentary tooth. This suggests that the habitat of the assemblage correspond to shallow, littoral waters. Although no detailed sedimentological study was carried out, we tentatively interpret the paleoenvironment as 
an estuary. This is suggested by the presence of coal seams, which may have orignated as poorly drained marshes. The large-scale cross-laminated sandstones can possibly be attributed to either migrating barrier bars at the estuary entrance or to bayhead deltas where the river entered the system (Le Roux et al., 2010). The stratigraphy of the studied section also supports this notion, displaying strata with wood remains and leaf imprints located stratigraphically close to the host beds of the elasmobanch assemblage.

\subsection{Relative age}

The evaluation of the known biochron (Table 1) shows that $M$. praecursor is the only species exclusively constrained to the Eocene (Capetta, 1987). On the other hand, the youngest known records of Ischyodus dolloi are restricted to the Late Eocene (Ward and Grande, 1991), whereas the genera $A b$ dounia and Galeorhinus are only known since the Early Eocene (Cappetta, 1980b; Cappetta, 1987) . The only exception is constituted by Carcharoides catticus, previously described in Oligocene-Miocene beds in both hemispheres (Philippi, 1846; Cappetta, 1987). This could be interpreted as the oldest known record of this species (or, alternatively, the youngest records of M. praecursor and I. dolloi). The presence of serrated cutting edges on Carcharoides totuserratus could be interpreted as a derived character from a taxon without serrations (such as C. catticus). A similar situation is seen between Carcharodon carcharias Linnaeus, 1758 and Cosmopolitodus hastalis (Agassiz, 1843), the latter possibly being the ancestor of the former (Nyberg et al., 2006). Furthermore, it is consistent with the presence of the derived species $C$. totuserratus exclusively in the Southern Hemisphere during the Oligocene-Miocene, with two records in the Pacific (Fitzgerald, 2004; Suárez et al., 2006) and one in the Atlantic Ocean (Cione and Expósito, 1980).

\subsection{Paleobotany}

The relative abundance of pteridophytes, pinophytes and angiosperms of the genus Nothofagus, indicates environmental requirements of humidity and temperature compatible with a temperate and wet climate, similar to that recognized during the Eocene on Seymour Island, Antarctica (Askin, 1989; Cione et al., 2007), suggesting that this floristic assemblage existed previous to the large climatic changes registered since the Eocene/Oligocene boundary (Lawver and Gahagan, 2003). However, the recognized diversity cannot provide more accurate chronostratigraphic information, although all the recognized taxa are known during the Eocene (Barreda and Palazzesi, 2007). On the other hand, Torres et al. (2009) recognized a rich diversity of palynomorphs in lower levels of the Loreto Formation, including 40 continental taxa of pterydophytes, and pollen of pinophytes and angiosperms, while recovered macroflora were represented by 30 leaf imprints with an abundant content of Nothofagus lanceolata Dusén, $N$. variabilis Dusén, and. $N$. subferruginea Dusén, together with Hydrangea inserta Berry, and Araucaria pichileufensis Berry. According to this diversity from lower levels of the Loreto Formation, there is thus no conflict with the present age proposal.

\subsection{U-Th-Pb data}

Both analysed samples have a very precise concordant dominant Late Eocene (Priabonian) grouping of detrital zircon grains. This is interpreted as the maximum possible sedimentation age of the rocks in which they occur. The relative probability pattern of the detrital ages, with the maximum peak being the youngest, suggests that very probably sedimentation took place at around this time. Surprisingly, no rocks with similar ages have been found in the South Patagonian Batholith (SPB, Hervé et al., 2007), lying $c a .100 \mathrm{~km}$ to the west and southwest, which would be the most obvious source of clastic material for the Rio de Las Minas depositional area. However, the 67 to 162 Ma zircon ages in the Las Minas 2008-02 sample, testify to a provenance from the SPB rocks, as the bulk of the batholith formed during that time span. A hitherto undated part of the SPB, or a different, not presently exposed (?) magmatic (volcanic?) body, must be considered to explain the presence of the Late Eocene igneous detrital zircons in the Rio las Minas studied succession. Further consideration of the provenance and tectonic implications of the detrital zircon assemblage will be given elsewhere.

\subsection{Associated vertebrate fauna}

Two bone fragments of fossil penguins were recovered from the Loreto Formation and described by Sallaberry et al. (2010). The material includes an 
ungual phalanx (SGO.PV.6652) and a tarsometarsal fragment (SGO.PV.6653), but the fragmentary condition of these remains does not allow them to be identified to genus or species level. Nevertheless, the ungual phalanx SGO.PV 6652 is identical to one figured by Jadwiszczak (2006; Fig. 19, i-j), and identified as an indeterminate spheniscid. On the other hand, the size of the tarsometatarsus matches that of endemic spheniscid penguins only known in the Late Eocene of the La Meseta Formation of Seymour Island in Antarctica. This group includes the species Mesetaornis polaris, Delphinornis gracilis, Delphinornis larseni, Delphinornis arctowskii, Delphinornis sp., and Marambiornis exilis, all characterized by a distinctively smaller size in comparison with common, larger Eocene penguins of the Weddellian Biogeographic Province. Additionally, the presence of well-fused metatarsals in SGO.PV.6653 compared to Neogene and extant species of spheniscids, indicates that this specimen has affinities with Paleogene members of this clade (Simpson, 1946; Acosta Hospitaleche et al., 2007). What is more, strongly fused metatarsals such as those of SGO.PV.6653 are a common character of all Eocene penguins (e.g., Clarke et al., 2007; Myrcha et al., 2002), this character is absent from crown spheniscids such as those from the Neogene (Göhlich, 2007) and extant species. Eocene penguins had a widespread distribution in the Southern Hemisphere, contrary to the scarce, known Paleocene distribution of these birds. In southernmost Chile other fossil spheniscids are represented by at least one genus, namely Palaeeudyptes Hector (SGO. PV.6585) recovered from Eocene beds of the Río Turbio Formation. All these data partially support the proposed Eocene age in this paper.

\section{Conclusions}

The fossil cartilaginous fishes from Río de Las Minas constitute the southernmost assemblage of this group in South America. The presence of Carcharias aff. 'hopei' (Agassiz), Striatolamia macrota (Agassiz), Macrorhizodus praecursor (Leriche), Abdounia sp. and Ischyodus dolloi Leriche supports an Eocene age for the hosting strata, while the presence of Carcharoides catticus (Philippi), previously known in Oligocene beds of the Northern Hemisphere (except for one dubious record in the Cenomanian of Egypt), suggests the relative age of the assemblage closer to the Eocene/Oligocene boundary. Additionally, this diversity seems to be typical of cold to temperate, shallow waters not deeper than $30 \mathrm{~m}$, being consistent with climate and seaway models during the Eocene and previous to the major changes experienced in the Southern Hemisphere during the Oligocene. The associated penguin bones found in the same beds are very fragmentary, although the presence of strongly-fused metatarsals can be distinguished, these being observed only in Eocene penguins from the Southern Hemisphere. The rich paleobotanic assemblage recognized in the Loreto Formation does not conflict with the relative age based on fossil vertebrates, although it cannot provide a more precise age due to poor chronostratigraphic resolution of the taxa. Finally, the absolute age obtained from the analyzed zircon grains indicates a very well defined peak at $36.48 \pm 0.47 \mathrm{Ma}(\mathrm{MSWD}=1.5)$. Considering the stratigraphic position of the studied section in the upper part of the Loreto Formation, all the data presented above indicate that most of this unit can be constrained to a minimal Priabonian age, but without discarding the eventual presence of Oligocene beds in the uppermost section. These remaining units are located several meters above the studied section, being mostly covered by vegetation, and represent a very minor portion of the whole formation.

\section{Acknowledgments}

This study was supported by the Antarctic Ring Projects (Anillo de Ciencia Antártica ARTG-04, 2006-2009, and Anillo de Ciencia Antártica ACT-105, 2010-2011 ConicytChile), was authorized for the collection of fossil samples in the field by the National Monuments Council (Consejo de Monumentos Nacionales-Chile) on September, 2010. Dr. G. Arratia (Museum of Natural History, University of Kansas, U.S.) and Dr. N. Malumián (Universidad de Buenos Aires, Argentina) are especially acknowledged for their critical review and valuable comments that helped to improve the manuscript. Special thanks to Dr. L.A. Cione (Universidad de La Plata, Argentina) for his review of an early draft of the manuscript and valuable comments. J. Quezada (SEREMI Medio Ambiente-Magallanes) is acknowledged for his assistance with access to the location and all his good will. We are also grateful to P. De Schutter (Elasmo.com), for discussions and providing valuable literature that improved this study. Finally, our sincere thanks to S.B. Cunningham (Tertiary Research Group), for his comments, help and sharing his expertise on Striatolamia teeth. R.E. Yury-Yáñez was funded by a master's degree CONICYT-Chile scholarship from the 'Programa de Formación de Capital Humano Avanzado'. 


\section{References}

Acosta Hospitaleche, C.; Tambussi, C.; Donato, M.; Cozzuol, M. 2007. A new Miocene penguin from Patagonia and its phylogenetic relationships. Acta Palaeontologica Polonica 52 (2): 299-314.

Agassiz, L. 1833-1844. Recherches sur les poissons fossiles. 5 vols.: $1420 \mathrm{p}$.

Ameghino, F. 1901. L'age des formations sédimentaires de Patagonie. Anales de la Sociedad Científica Argentina 51: 20-39, 65-91.

Arambourg, C. 1935. Note préliminaire sur les vertébrés fossiles des phosphates du Maroc. Bulletin de la Société géologique de France 5 (5): 413-439.

Arambourg, C. 1952. Les Vertébrés fossiles des gisements de phosphates (Maroc, Algérie, Tunisie). Service Géologique du Maroc, Notes et Mémories 92: 1-372.

Arratia, G.; Cione, A. 1996. The Record of Fossil Fishes of southern South America. In Contribution of southern South America to Vertebrate Paleontology (Arratia, G.; editor). Münchner Geowissenschaft Abhanlungen 30: 9-72.

Askin, R.A. 1989. Endemism and heterochroneity in the Late Cretaceous (Campanian) to Paleocene palynofloras of Seymour Island, Antarctica: implications for origins, dispersal and paleoclimates of southern floras. In Origins and Evolution of the Antarctic Biota (Crame, J.A.; editor). Geological Society, Special Publication 47: 107-119.

Barreda, V.D.; Palazzesi, L. 2007. Patagonian vegetation turnovers during the Paleogene-Early Neogene: origin of arid-adapted floras. The Botanical Review 73: 31-50.

Berg, L.S. 1958. System der rezenten und fossilen Fischartigen und Fische. Deustch Verlag der Wissenschaften: $310 \mathrm{p}$.

Biddle, K.; Uliana, R.; Mitchum, J.; Fitzgerald, M.; Wright, R. 1986. The Stratigraphic and structural evolution of the central and eastern Magallanes Basin, southern South America. Association of Sedimentology, Special Publication 8: 41-61.

Bonaparte, C.L. 1832. Selachorum Tabula Analytica. Nuovi Annali di Scienze Naturali (Bologna) 1: 195-214.

Bonaparte, C.L. 1838. Selachorum tabula analytica. Nuovi Annali della Science Naturali (Bologna) 1 (2): 195-214.

Bonnaterre, J.P. 1788. Tableau encyclopèdique et méthodique des trois régnes de la nature. Ichthyologie: 215 p. Paris.

Cappetta, H. 1980a. Les sélaciens du Crétacé Supérieur du Liban. 2: Batoides. Palaeontographica Abteilung (A) 168: 149-229.
Cappetta, H. 1980b. Modification du statut générique de quelques espèces de sélaciens crétacés et tertiaires. Palaeovertebrata 10 (1): 29-42.

Cappetta, H. 1987. Handbook of Paleoichthyology. Volume 3b: Chondrichthyes II. Mesozoic and Cenozoic Elasmobranchii (Schultze, H.-P.; editor). Gustav Fischer Verlag: 193 p.

Cappetta, H.; Nolf, D. 2005. Révision des quelques Odontaspididae (Neoselachii: Lamniformes) du Paléocène et de l'Eocène du Bassin de la mer du Nord. Bulletin de 1'Institut Royal des Sciences Naturelles de Belgique, Sciences de la Terre 75: 237-266.

Case, G.R.; Borodin, P.D. 2000. A Middle Eocene Selachian Fauna from the Castle Hayne Limestone Formation of Duplin County, North Carolina. Münchner Geowissenschaft Abhandlungen 39: 17-32.

Chapman, F. 1913. Note on the occurrence of the Cainozoic shark, Carcharoides, in Victoria. Victorian Naturalist 30: 142-143.

Charrier, R.; Lahsen, A. 1968. Contribution a l'étude de la limite Crétacé-Tertiaire de la Province de Magellan, extreme-sud du Chili. Revue de Micropaléontolologie 11: 111-120.

Charrier, R.; Lahsen, A. 1969. Stratigraphy of Late CretaceousEarly Eocene of Seno Skyring-Estrecho of Magellan area, Magallanes Province, Chile. American Association of Petroleum Geologists Bulletin 53 (3): 568-590.

Cione, A.L. 1978. Aportes paleontológicos al conocimiento de la evolución de las paleotemperaturas en el área austral de América del Sur durante el Cenozoico. Ameghiniana 15 (1-2): 183-208.

Cione, A.L.; Expósito, S. 1980. Chondrichthyes del 'Patagoniano' s.l. de Astra, Golfo de San jorge, Provincia de Chubut, Argentina. Su significado paleoclimático y paleobiogeográfico. In Congreso Argentino de Paleontología y Bioestratigrafía, No. 2 y Congreso Latinoamericano de Paleontología, No. 1, Actas 2: 275-290.

Cione, A.L.; Mennucci, J.A.; Santalucita, F.; Acosta, C. 2007. Local extinction of sharks of genus Carcharias Rafinesque, 1810 (Elasmobranchii, Odontaspididae) in the eastern Pacific Ocean. Revista Geológica de Chile 34 (1): 139-145.

Cione, A.L.; Reguero, M. 1994. New records of the sharks Isurus and Hexanchus from the Eocene of Seymour Island, Antarctica. Proceedings of the Geologists Association 105: 1-14.

Clarke, J.A.; Ksepka, D.T.; Stucchi, M.; Urbina, M.; Giannini, N.; Bertelli, S.; Narváez, Y.; Boyd., C. A. 2007. Paleogene equatorial penguins challenge the proposed relationship between biogeography, diversity, and Ce- 
nozoic climate change. Proceedings of the National Academy of Sciences (US) 104: 11545-11550.

Compagno, L.J.V. 1973. Interrelationships of living elasmobranchs. In Interrelationships of Fishes (Greenwood, P.H.; Miles, R.S.; Patterson, C.; editors). Supplement I to Zoological Journal of the Linnean Society of London 53: 15-61.

Compagno, L.J.V. 1977. Phyletic relationships of living sharks and rays. American Zoologist 17: 303-322.

Compagno, L.J.V. 1984. FAO species catalogue. Vol. 4. Sharks of the world. An annotated and illustrated catalogue of sharks species known to date. Part 1. Hexanchiformes to Lamniformes. FAO Fishery Synopsis No. 125, 4 (1): 249 p.

Compagno, L.J.V. 2001 FAO species catalogue. Sharks of the world. An annotated and illustrated catalogue of sharks species known to date. Part 1. Hexanchiformes to Lamniformes. FAO Fishery Synopsis No. 125, 4 (2): $269 \mathrm{p}$.

Cookson, I.C.; Cranwell, L.M. 1967. Lower Tertiary microplankton, spores and pollen grains from southernmost Chile. Micropaleontology 13: 204-216.

Cuvier, G.L.C.F.D. 1817. La règne animal distribue d'après son organisation. Tome II. Les Reptiles, les Poissons, les Mollusques et les Annelides: 532 p.

Cvancara, A.M.; Hoganson, J.W. 1993. Vertebrates of the Cannonball Formation (Paleocene) in North and South Dakota. Journal of Vertebrate Paleontology 13: 1-23.

De Blainville, H.M. 1816. Prodrome d'une nouvelle distribution systématique du règne animal. Bulletin des Sciences par la Société Philomatique du Paris 8: 113-124.

De Buen, F. 1926. Catálogo ictiológico del Mediterráneo español y de Marruecos recopilando lo publicado sobre peces de las costas mediterráneas y próximas del Atlántico (Mar de España). Commission Internationale pour l'exploration scientifique de la mer Méderiterranée: $221 \mathrm{p}$.

Duméril, A.M. 1806. Zoologie analytique ou méthode naturelle de classification des animaux, rendu plus facile à l'aide de tableaux synoptiques: $344 \mathrm{p}$.

Egerton, P.G. 1843. On some new species of fossil chimaeroid fishes, with remarks on their general affinities. Proceedings of the Geological Society of London 4: 153-157.

Fasola, A. 1969. Estudio palinológico de la Formación Loreto (Terciario Medio), Provincia de Magallanes, Chile. Ameghiniana 6: 3-49.

Fildani, A.; Hessler, A. 2005. Stratigraphic record across a retroarc basin inversion: Rocas Verdes-Magallanes
Basin, Patagonian Andes, Chile. Geologic S.A. Bulletin 117 (11/12): 1596-1614.

Fitzgerald, E.M.G. 2004. A review of the Tertiary fossil Cetacea (Mammalia) localities in Australia. Memoirs of Museum of Victoria 61 (2): 183-208.

Garman, S. 1901. Genera and families of the Chimaeroids. Proceedings of the New England Zoological Club 2: 75-77.

Garman, S. 1913. The Plagiostomia (Sharks, Skates and Rays). Memoirs of the Museum of Comparative Zoology at Hardvad College 36: 538 p.

Glikman, L. 1964. Akuly paleogena i ikh stratigraficheskoe znachenie. Akademii Nauk Soyuza Sovetskikh Sotsialisticheskikh Respublik: 228 p.

Göhlich, U. 2007. The oldest fossil record of the extant penguin genus Spheniscus -a new species from the Miocene of Peru. Acta Palaeontologica Polonica 52 (2): 285-298.

Gradstein, F.M., Ogg, J.G.; Van Kranendonk, M. 2008. Geologic Time Scale 2008. http://www.stratigraphy. org/GTS2008.pdf

Gray, J.E. 1851. List of the specimens of fish in the collection of the British Museum. Part I. Condropterygii. British Museum of Natural History: 160 p.

Hauser, A. 1964. La zona glauconítica en la plataforma Springhill, Magallanes, Chile. Degree memory (Unpublished), Escuela de Geología, Universidad de Chile: 261-266.

Hemmer, A. 1935. Geología de los terrenos petrolíferos de Magallanes y las exploraciones realizadas. Boletín Minero 139-149: 181-197. Santiago, Chile

Hervé, F.; Pankhurst, R.J.; Fanning, C.M.; Calderón, M.; Yaxley, G.M. 2007. The South Patagonian batholith: 150 my of granite magmatism on a plate margin. Lithos 97: 373-394.

Hoffstetter, R.; Fuenzalida, H.; Cecioni, G. 1957. Chili In Lexique Stratigraphique International. Centre National de la Recherche Scientifique V: 444 p. France.

Huxley, T.H. 1880. On the application of the laws of evolution to the arrangement of the Vertebrata, and more particularly of the Mammalia. Proceedings of the Zoological Society of London 43: 649-661.

Jadwiszczak, P. 2006. Eocene penguins of Seymour Island, Antarctica: Taxonomy. Polish Polar Research 27: 3- 62.

Jordan, D.S. 1898. Description of a species of fish (Mitsukurina owstoni) from Japan, the type of a distinct family of lamnoid sharks. Proceedings of the California Academy of Sciences 3: 199-204.

Jordan, D.S.; Evermann, B.W. 1896. The fishes of North and Middle America. Bulletin of the United States National Museum 47: 1-1240. 
Katz, H. 1963. Revision of cretaceous stratigraphy in Patagonian Cordillera of Última Esperanza, Magallanes province, Chile. American Association of Petroleum Geologists Bulletin 47: 506-524.

Kent, B.W. 1994. Fossil Sharks of the Chesapeake Region. Egan Rees and Boyer Eds.: 146 p. Maryland.

Kniker, H. 1949. Report of samples collected by J. S. Barwick on Peninsula Brunswick. Field season of 1948-49 to accompany his report on Tertiary stratigraphic studies in eastern Peninsula Brunswick, Tierra del Fuego. (Unpublished) ENAP, Chile.

Kriwet, J. 2005. Additions to the Eocene Selachian fauna of Antarctica with comments on Antarctic selachian diversity. Journal of Vertebrate Paleontology 25 (1): 1-7.

Lawver, L.A.; Gahagan, L.M. 2003. Evolution of Cenozoic seaways in the circum-Antarctic region. Palaeogeography, Palaeoclimatology, Palaeoecology, 198: 11-37.

Leriche, M. 1902. Les poissons tertiaires de la Belgique I. Les poissons paléocènes. Mémoires du Musée Royale du Historie Naturelle du Belgique 2 (5): 48 pp.

Leriche, M. 1905. Les poissons tertiaires de la Belgique. II. Les poissons éocènes. Mémoires du Musée Royale du Historie Naturelle du Belgique 11 (3): 49-228.

Le Roux, J.P.; Puratich, J.; Mourgues, F.A.; Oyarzun, J.L.; Otero, R.A.; Torres, T.; Hervé, F. 2010. Estuary deposits in the Rio Baguales Formation (ChattianAquitanean), Magallanes Province, Chile. Andean Geology 37 (2): 329-344.

Linnaeus, C. 1758. Systema naturae per regna tria naturae, secundum classes, ordines, genera, species, cum characteribus, differentiis, synonymis, locis. Editio decima, reformata, Tomus I. Holmiae. (Laurentii Salvii): (1-4): 1-824.

Long, D.J. 1992. Sharks from The La Meseta Formation (Eocene) Seymour Island, Antarctic Peninsula. Journal of Vertebrate Paleontology 12 (1): 11-32.

Long, D.J. 1993. Late Miocene and Early Pliocene fish assemblages from the north-central coast of Chile. Tertiary Research 14 (3): 117-126.

Ludwig, K.R. 2001. SQUID 1.02, A User's Manual; Berkeley Geochronology Center, Special Publication 2: 19 p.

Malumián, N.; Jannou, G. 2010. Los Andes Fueguinos: el registro micropaleontológico de los mayores acontecimientos paleooceanográficos australes del Campaniano al Mioceno. Andean Geology 37 (2): 345-374.

Martínez-Pardo, R.; Osorio, R.; Lillo, J. 1965. Edad de la Formación Ciervos. Resúmenes Sociedad Geológica de Chile 10 (1): 5-6.

Martínez-Pardo, R.; Martínez. R. 1989. Reinterpretation of Boltovskoyella (benthic foraminiferal genus) as Neogene TransAndean chronostratigraphic event in southern South America. The Pacific, bridge or barrier? In Pacific Science Association Inter-Congress No. 6, Abstracts. Valparaíso, Chile.

Müller, J.; Henle, F. 1837. Ueber die Gattungen der Plagiostomen. Archiv für Naturgeschichte 3: 394-401.

Müller, J.; Henle, F. 1838. On the generic characters of cartilaginous fishes, with descriptions of new genera. Magazine of Natural History 2: 33-37.

Muñoz-Ramírez, C.P.; Zambrano, Z.; Montoya, G.; Moyano, H. 2007. Dientes de tiburones y rayas (Chondrichthyes, Elasmobranchii) de la Formación Quiriquina aflorante en Talcahuano, Chile Central. Boletín de la Sociedad de Biología de Concepción 78: 7-22.

Muñoz-Ramírez, C.; Moyano, H.; Palma-Heldt, S. 2008. Dientes fósiles de tiburones y rayas presentes en el área de la Bahía de Concepción, VIII Región, Chile Central. In Simposio-Paleontología en Chile No.1, Libro de Actas: 69-73. Santiago.

Myrcha A.; Jadwiszczak, P.; Tambussi, C.; Noriega, J.; Gaździcki, A.; Tatur, A; Del Valle, R. 2002. Taxonomic revision of Eocene Antarctic penguins based on tarsometatarsal morphology. Polish Polar Research, 23 (1): 5-46.

Natland, M.L.; González, E.; Cañón, A.; Ernst, M. 1974. A system of stages for correlation of Magallanes Basin sediments. Memoirs of the Geological Society of America 139: 755-761.

Nolf, D. 1988. Dents de Requins et de Raies du Tertiaire de la Belgique. Institut Royal des Sciences Naturelles de Belgique: 184 p.

Nyberg, K.G.; Ciampaglio, C.N.; Wray, G.A. 2006. Tracing the ancestry of the great white shark, Carcharodon Carcharias, using morphometric analyses of fossil teeth. Journal of Vertebrate Paleontology 26 (4): 806-814.

Obruchev, D.V. 1953. Studies on edestids ad the works of A. P. Karpinski. U.S.S.R Academy of Sciences, Works on Palaeontological Institute Publication 45: 1-86.

Oliver-Schneider, C. 1936. El Odontaspis elegans (Agassiz) en el Terciario Eoceno de Chile. Comunicaciones del Museo de Concepción 1 (4): 77-78.

Patterson, C. 1965. The pylogeny of the Chimaeroids. Phylosophical Transactions of the Royal Society of London (B) 249: 101-219.

Philippi, R.A. 1846. Ueber Tornatella abbreviata, Otodus mitis, Otodus catticus und Myliobatis Testae. Palaeontographica I: $24 \mathrm{p}$.

Popov, E.V. 1996. The use of ontogenetic series in the study of tooth plates of Cretaceous-Paleogene chimaeroid fishes. In Conference of the Paleontological Society No 42, Abstracts, Russian Academy of Science: 6970. Saint Petersburg. 
Quattrochio M.; Sarjeant, A.S. 2003. Dinoflagellates from the Chorrillo Chico Formation (Paleocene) of southern Chile. Ameghiniana 40 (2): 129-153.

Rafinesque, C.S. 1810. Caratteri di alcuni nuovi generi e nuove specie di animali e pinate della Sicilia, con varie osservazioni sopra i medisimi. 3-69.

Rana, R.S.; Kumar, K.; Singh, H. 2004. Vertebrate fauna from the subsurface Cambay Shale (Lower Eocene), Vastan Lignite Mine, Gujarat, India. Current Science 89 (9): 1060-1013.

Risso, A. 1810. Ichthyologie de Nice. Schoell XXVI: 388 p. Paris.

Sallaberry, M.A.; Yury-Yáñez, R.E.; Otero, R.A.; Soto-Acuña, S.; Torres, T. 2010. Eocene Birds From The western margin of southernmost South America. Journal of Paleontology 84 (6): 1061-1070.

Simpson, G.G. 1946. Fossil penguins. Bulletin of the American Museum of Natural History 87: 1-100.

Stahl, B.J.; Chatterjee, S. 2003. A Late Cretaceous callorhynchid Chondrichthyes, Holocephali) from Seymour Island, Antarctica. Journal of Vertebrate Paleontology 22 (4): 848-850.

Suárez, M.E.; Marquardt, C. 2003. Revisión Preliminar de las Faunas de Peces Elasmobranquios del Mesozoico y Cenozoico de Chile: Su valor como indicadores Cronoestratigráficos. In Congreso Geológico Chileno No. 10, Actas (formato digital), Sección temática 3: 9 p. Concepción.

Suárez, M.E.; Encinas, A.; Ward, D. 2006. An Early Miocene elasmobranch fauna from the Navidad Formation, Central Chile, South America. Cainozoic Research 4 (1-2): 3-18.

Suárez, M.E.; Lamilla, J.; Marquardt, C. 2004. Peces Chimaeriformes (Chondrichthyes, Holocephali) del Neógeno de la Formación Bahía Inglesa (Región de Atacama, Chile). Revista Geológica de Chile 31 (1): 105-117.

Suárez, M.E.; Quinzio, L.A.; Fritis, O.; Bonilla, R. 2003. Aportes al conocimiento de los vertebrados marinos de la Formación Quiriquina. In Congreso Geológico Chileno No. 10, Actas (formato digital), Sección temática 3: 7 p. Concepción.

Tavera, J. 1946. Las Migraciones de fauna entre el Senoniano superior y Terciario y la fauna senoniana y terciaria de Magallanes. In Congresso Panamericano de Engenharia de Minas e Geología No. 2, Anais, Tesis 171: 159 p. Petropolis, Brazil.

Terada, K.; Asakawa, T.O.; Nishida, H. 2006. Fossil woods from the Loreto Formation of Las Minas, Magallanes (XII) Region, Chile. In Post-Cretaceous Floristic
Changes in Southern Patagonia, Chile (Nishida, H.; editor). Chuo University: 91-101. Tokyo.

Thomas, C. 1949. Geology and petroleum explorations in Magallanes Province, Chile. American Association of Petroleum Geologists Bulletin 33: 1553-1578.

Torres, T.; Méon, H.; Otero, R.A.; Galleguillos, H. 2009. Palinoflora y macroflora de la Formación Loreto, Punta Arenas, Región de Magallanes, Chile. In Congreso Geológico Chileno No. 12, Simposio 12, Relaciones Geológicas y Paleontológicas entre Antártica y Patagonia, Actas (formato digital): 5 p. Santiago.

Torres, T.; Otero, R.A.; Palma-Heldt, S. 2008. Nuevos registros de tafoflora y vertebrados marinos en la Formación Loreto, Río de Las Minas, Punta Arenas, Chile. In Antártica y Sudamérica: Ciencia en el Año Polar Internacional. Libro de resúmenes del Simposio Latinoamericano sobre Investigaciones Antárticas, No. 4 y Reunión Chilena de Investigación Antártica, No. 7 (Leppe, M.; Gimpel, C.; Leiva, L.F.; editores). Publicación del Instituto Antártico Chileno: 423-427. Valparaíso.

Ward, D.J. 1973. The English Palaeogene chimaeroid fishes. Proceedings of the Geologists Association 84: 315-330.

Ward, D. 1988. Hypotodus verticalis (Agassiz, 1843), Hypotodus robustus Leriche (1921) and Hypotodus heinzelini (Casier, 1967), Chondrichthyes, Lamniformes, junior synonyms of Carcharias hopei (Agassiz,1843). Tertiary Research 10 (1): 1-12.

Ward, D.; Grande, L. 1991. Chimaeroid fish remains from Seymour Island, Antarctic Peninsula. Antarctic Science 3 (3): 323-330.

Welton, B.; Zinsmeister, W. 1980. Eocene neoselachians from the La Meseta Formation, Seymour Island, Antarctic Peninsula. Natural History Museum of Los Angeles County, contributions in Science 329: 1-10.

Werner, C. 1989. Die Elasmobranchier-Fauna des Gebel Dist Member der Bahariya Formation (Obercenoman) der Oase Bahariya, Agypten. PalaeoIchthyologica 5: 1-112.

Williams, I.S. 1998. U-Th-Pb geochronology by Ion Microprobe. In Applications of microanalytical techniques to understanding mineralizing processes (Mc Kibben, M.A.; Shanks, W.C.III; Ridley,W.I. ; editors). Reviews in Economic Geology 7: 1-35.

Zangerl, R. 1979. New chondrichthyans from the Mazon Creek fauna (Pennsylvanian) of Illinois. In Mazon Creek Fossils (Nitecki, M.H.; editor). Academic Press: 449-500. 


\section{APPENDICES}

APPENDIX I. SUMMARY OF SHRIMP U-Pb ZIRCON RESULTS FOR SAMPLE LAS MINAS 2008-01.

\begin{tabular}{|c|c|c|c|c|c|c|c|c|c|c|c|c|c|c|}
\hline \multirow[b]{2}{*}{$\begin{array}{c}\text { Grain } \\
\text { spot }\end{array}$} & \multirow[b]{2}{*}{$\begin{array}{c}\mathrm{U} \\
\text { (ppm) }\end{array}$} & \multirow[b]{2}{*}{$\begin{array}{c}\text { Th } \\
\text { (ppm) }\end{array}$} & \multirow[b]{2}{*}{$\mathbf{T h} / \mathbf{U}$} & \multirow[b]{2}{*}{$\begin{array}{l}{ }^{206} \mathrm{~Pb}^{*} \\
(\mathrm{ppm})\end{array}$} & \multirow[b]{2}{*}{$\begin{array}{l}{ }^{204} \mathrm{~Pb} / \\
{ }^{206} \mathrm{~Pb}\end{array}$} & \multirow[b]{2}{*}{$\begin{array}{l}f_{206} \\
\%\end{array}$} & \multicolumn{5}{|c|}{ Total Ratios } & \multicolumn{2}{|c|}{$\begin{array}{r}\text { Radiogenic } \\
{ }^{206} \mathrm{~Pb} /\end{array}$} & \multirow{2}{*}{$\begin{array}{c}\text { Age (Ma) } \\
\pm\end{array}$} \\
\hline & & & & & & & $\begin{array}{l}{ }^{238} \mathrm{U} / \\
{ }^{206} \mathrm{~Pb}\end{array}$ & \pm & $\begin{array}{l}{ }^{207} \mathrm{~Pb} / \\
{ }^{206} \mathrm{~Pb}\end{array}$ & \pm & $\begin{array}{c}{ }^{206} \mathrm{~Pb} / \\
{ }^{238} \mathrm{U}\end{array}$ & \pm & $\begin{array}{c}{ }^{206} \mathrm{~Pb} / \\
{ }^{238} \mathrm{U}\end{array}$ & \\
\hline 1.1 & 123 & 77 & 0.63 & 0.6 & 0.000774 & 1.60 & 172.2 & 3.2 & 0.0594 & 0.0031 & 0.0057 & 0.0001 & 36.7 & 0.7 \\
\hline 2.1 & 28 & 12 & 0.42 & 0.2 & 0.012858 & 9.96 & 157.2 & 4.7 & 0.1256 & 0.0115 & 0.0057 & 0.0002 & 36.8 & 1.3 \\
\hline 3.1 & 221 & 175 & 0.79 & 19.2 & 0.000089 & $<0.01$ & 9.919 & 0.110 & 0.0599 & 0.0006 & 0.1009 & 0.0011 & 619.6 & 6.7 \\
\hline 4.1 & 36 & 22 & 0.61 & 0.2 & - & 6.94 & 162.1 & 4.8 & 0.1017 & 0.0106 & 0.0057 & 0.0002 & 36.9 & 1.2 \\
\hline 5.1 & 97 & 95 & 0.98 & 0.5 & - & 2.46 & 165.7 & 3.2 & 0.0662 & 0.0049 & 0.0059 & 0.0001 & 37.8 & 0.8 \\
\hline 6.1 & 67 & 51 & 0.77 & 0.3 & - & 4.64 & 168.4 & 3.9 & 0.0834 & 0.0071 & 0.0057 & 0.0001 & 36.4 & 0.9 \\
\hline 7.1 & 93 & 99 & 1.07 & 0.5 & 0.002509 & 4.11 & 169.1 & 3.4 & 0.0793 & 0.0057 & 0.0057 & 0.0001 & 36.4 & 0.8 \\
\hline 8.1 & 111 & 113 & 1.03 & 0.6 & 0.003620 & 2.31 & 167.5 & 3.4 & 0.0650 & 0.0046 & 0.0058 & 0.0001 & 37.5 & 0.8 \\
\hline 9.1 & 87 & 90 & 1.03 & 0.4 & 0.001697 & 3.49 & 173.3 & 3.6 & 0.0743 & 0.0059 & 0.0056 & 0.0001 & 35.8 & 0.8 \\
\hline 10.1 & 71 & 38 & 0.53 & 0.4 & 0.001736 & 2.55 & 169.3 & 3.8 & 0.0669 & 0.0062 & 0.0058 & 0.0001 & 37.0 & 0.9 \\
\hline 11.1 & 56 & 42 & 0.75 & 0.3 & 0.007013 & 3.44 & 164.7 & 4.5 & 0.0740 & 0.0070 & 0.0059 & 0.0002 & 37.7 & 1.1 \\
\hline 12.1 & 95 & 95 & 1.00 & 0.5 & 0.004288 & 3.82 & 163.8 & 3.2 & 0.0770 & 0.0052 & 0.0059 & 0.0001 & 37.7 & 0.8 \\
\hline 13.1 & 60 & 50 & 0.83 & 0.3 & 0.007830 & 5.67 & 167.6 & 4.0 & 0.0916 & 0.0076 & 0.0056 & 0.0001 & 36.2 & 0.9 \\
\hline 14.1 & 241 & 136 & 0.56 & 1.4 & 0.000559 & 0.74 & 151.7 & 2.2 & 0.0527 & 0.0026 & 0.0065 & 0.0001 & 42.0 & 0.6 \\
\hline 15.1 & 82 & 77 & 0.93 & 0.4 & 0.003264 & 2.22 & 170.7 & 3.7 & 0.0644 & 0.0055 & 0.0057 & 0.0001 & 36.8 & 0.8 \\
\hline 16.1 & 33 & 18 & 0.54 & 0.2 & 0.017226 & 9.26 & 162.7 & 5.1 & 0.1200 & 0.0120 & 0.0056 & 0.0002 & 35.8 & 1.3 \\
\hline 17.1 & 165 & 100 & 0.60 & 0.8 & 0.004997 & 3.63 & 173.7 & 2.9 & 0.0755 & 0.0041 & 0.0055 & 0.0001 & 35.7 & 0.6 \\
\hline 18.1 & 202 & 110 & 0.55 & 2.1 & 0.000942 & 0.83 & 82.03 & 1.07 & 0.0541 & 0.0020 & 0.0121 & 0.0002 & 77.5 & 1.0 \\
\hline 19.1 & 72 & 61 & 0.85 & 0.4 & 0.007329 & 4.12 & 164.0 & 3.5 & 0.0794 & 0.0083 & 0.0058 & 0.0001 & 37.6 & 0.9 \\
\hline 20.1 & 72 & 55 & 0.77 & 0.4 & 0.001982 & 7.57 & 168.2 & 3.6 & 0.1066 & 0.0071 & 0.0055 & 0.0001 & 35.3 & 0.8 \\
\hline 21.1 & 43 & 25 & 0.58 & 0.2 & 0.014823 & 9.43 & 159.4 & 4.2 & 0.1213 & 0.0095 & 0.0057 & 0.0002 & 36.5 & 1.1 \\
\hline 22.1 & 78 & 60 & 0.76 & 0.4 & 0.003496 & 7.67 & 168.9 & 3.5 & 0.1074 & 0.0066 & 0.0055 & 0.0001 & 35.1 & 0.8 \\
\hline 23.1 & 80 & 81 & 1.01 & 0.4 & 0.004111 & 3.77 & 168.5 & 3.5 & 0.0766 & 0.0054 & 0.0057 & 0.0001 & 36.7 & 0.8 \\
\hline 24.1 & 88 & 64 & 0.73 & 0.4 & 0.003520 & 6.97 & 172.5 & 3.5 & 0.1018 & 0.0064 & 0.0054 & 0.0001 & 34.7 & 0.8 \\
\hline 25.1 & 104 & 98 & 0.94 & 0.5 & 0.005751 & 3.27 & 169.3 & 3.2 & 0.0727 & 0.0046 & 0.0057 & 0.0001 & 36.7 & 0.7 \\
\hline 26.1 & 54 & 32 & 0.60 & 0.3 & - & 5.26 & 178.6 & 6.2 & 0.0883 & 0.0077 & 0.0053 & 0.0002 & 34.1 & 1.2 \\
\hline 27.1 & 68 & 49 & 0.72 & 0.4 & 0.007993 & 4.69 & 166.5 & 3.6 & 0.0839 & 0.0064 & 0.0057 & 0.0001 & 36.8 & 0.9 \\
\hline 28.1 & 76 & 76 & 1.00 & 0.4 & 0.000540 & 3.54 & 167.9 & 3.5 & 0.0748 & 0.0058 & 0.0057 & 0.0001 & 36.9 & 0.8 \\
\hline 29.1 & 438 & 89 & 0.20 & 5.0 & 0.000559 & 0.48 & 75.07 & 0.99 & 0.0515 & 0.0013 & 0.0133 & 0.0002 & 84.9 & 1.1 \\
\hline 30.1 & 102 & 99 & 0.97 & 0.5 & 0.003503 & 3.79 & 163.1 & 3.1 & 0.0768 & 0.0048 & 0.0059 & 0.0001 & 37.9 & 0.7 \\
\hline 31.1 & 84 & 70 & 0.83 & 0.4 & 0.000842 & 2.52 & 177.7 & 3.7 & 0.0667 & 0.0053 & 0.0055 & 0.0001 & 35.3 & 0.8 \\
\hline 32.1 & 79 & 49 & 0.61 & 0.4 & - & 6.05 & 167.5 & 3.5 & 0.0946 & 0.0064 & 0.0056 & 0.0001 & 36.1 & 0.8 \\
\hline 33.1 & 78 & 66 & 0.85 & 0.4 & 0.000328 & 4.49 & 157.7 & 3.5 & 0.0824 & 0.0058 & 0.0061 & 0.0001 & 38.9 & 0.9 \\
\hline 34.1 & 56 & 47 & 0.83 & 0.3 & 0.001472 & 9.46 & 164.5 & 3.8 & 0.1216 & 0.0085 & 0.0055 & 0.0001 & 35.4 & 0.9 \\
\hline 35.1 & 70 & 65 & 0.92 & 0.4 & 0.007705 & 5.85 & 161.8 & 3.7 & 0.0931 & 0.0062 & 0.0058 & 0.0001 & 37.4 & 0.9 \\
\hline 36.1 & 846 & 362 & 0.43 & 8.4 & 0.000306 & 0.32 & 86.36 & 0.94 & 0.0500 & 0.0011 & 0.0115 & 0.0001 & 74.0 & 0.8 \\
\hline 37.1 & 250 & 210 & 0.84 & 1.4 & 0.001709 & 0.69 & 158.0 & 2.2 & 0.0523 & 0.0023 & 0.0063 & 0.0001 & 40.4 & $\theta .6$ \\
\hline 38.1 & 270 & 223 & 0.83 & 1.3 & 0.000006 & 0.68 & 178.4 & 2.5 & 0.0521 & 0.0025 & 0.0056 & 0.0001 & 35.8 & 0.5 \\
\hline
\end{tabular}

Notes:

1. Uncertainties given at the one s level.

2. Error in Temora reference zircon calibration was $0.82 \%$ for the analytical session (not included in above errors but required when comparing ${ }^{206} \mathrm{~Pb} /{ }^{238} \mathrm{U}$ data from different mounts).

3. $\mathrm{f}_{206} \%$ denotes the percentage of ${ }^{206} \mathrm{~Pb}$ that is common $\mathrm{Pb}$.

4. Correction for common $\mathrm{Pb}$ made using the measured ${ }^{238} \mathrm{U} /{ }^{206} \mathrm{~Pb}$ and ${ }^{207} \mathrm{~Pb} /{ }^{206} \mathrm{~Pb}$ ratios following Tera and Wasserburg (1972) as outlined in Williams (1998).

5. For $\%$ Disc, $0 \%$ denotes a concordant analysis.

\begin{tabular}{|c|c|c|c|c|c|}
\hline & & Age & \pm no std & \pm include std & \\
\hline wtd ave dominant & 36.48 & 0.36 & 1.28 & 0.47 & 32 analyses, $\mathrm{MSWD}=1.5$ \\
\hline wtd ave best fit & 36.52 & 0.30 & 1.16 & 0.42 & 29 analyses, MSWD $=1.05$ \\
\hline
\end{tabular}




\begin{tabular}{|c|c|c|c|c|c|c|c|c|c|c|c|c|c|c|c|c|c|c|c|c|c|c|}
\hline \multirow[b]{2}{*}{$\begin{array}{c}\text { Grain } \\
\text { spot }\end{array}$} & \multirow[b]{2}{*}{$\begin{array}{c}\mathrm{U} \\
(\mathbf{p p m})\end{array}$} & \multirow[b]{2}{*}{$\begin{array}{c}\text { Th } \\
(\mathbf{p p m})\end{array}$} & \multirow[b]{2}{*}{ Th/U } & \multirow[b]{2}{*}{$\begin{array}{l}{ }^{206} \mathrm{~Pb}^{*} \\
(\mathrm{ppm})\end{array}$} & \multirow[b]{2}{*}{$\begin{array}{l}{ }^{204} \mathrm{~Pb} / \\
{ }^{206} \mathrm{~Pb}\end{array}$} & \multirow[b]{2}{*}{$\begin{array}{l}f_{206} \\
\%\end{array}$} & & tal Ra & & & & & ogenic $R$ & & & & & & & Age (Ma & & \\
\hline & & & & & & & $\begin{array}{l}{ }^{238} \mathrm{U} / \\
{ }^{206} \mathrm{~Pb}\end{array}$ & \pm & $\begin{array}{c}{ }^{207} \mathrm{~Pb} / \\
{ }^{206} \mathrm{~Pb}\end{array}$ & \pm & $\begin{array}{c}{ }^{206} \mathrm{~Pb} / \\
{ }^{238} \mathrm{U}\end{array}$ & \pm & $\begin{array}{c}{ }^{207} \mathrm{~Pb} / \\
{ }^{235} \mathrm{U}\end{array}$ & \pm & $\begin{array}{l}{ }^{207} \mathrm{~Pb} / \\
{ }^{206} \mathrm{~Pb}\end{array}$ & \pm & $\mathbf{r}$ & $\begin{array}{c}{ }^{206} \mathrm{~Pb} / \\
{ }^{238} \mathrm{U}\end{array}$ & \pm & $\begin{array}{l}{ }^{207} \mathrm{~Pb} / \\
{ }^{206} \mathrm{~Pb}\end{array}$ & \pm & $\begin{array}{c}\% \\
\text { Disc }\end{array}$ \\
\hline 1.1 & 162 & 84 & 0.52 & 0.8 & 0.003189 & 1.39 & 170.82 & 3.71 & 0.0578 & 0.0034 & 0.0058 & 0.0001 & - & - & - & - & - & 37.1 & 0.8 & - & - & - \\
\hline 2.1 & 227 & 92 & 0.40 & 2.3 & 0.001347 & 0.23 & 83.71 & 1.28 & 0.0494 & 0.0018 & 0.0119 & 0.0002 & - & - & - & - & - & 76.4 & 1.2 & - & - & - \\
\hline 3.1 & 43 & 21 & 0.49 & 0.2 & 0.001236 & 3.18 & 168.53 & 6.42 & 0.0719 & 0.0079 & 0.0057 & 0.0002 & - & - & - & - & - & 36.9 & 1.5 & - & - & - \\
\hline 4.1 & 58 & 36 & 0.62 & 0.3 & 0.008477 & 4.02 & 166.52 & 5.43 & 0.0786 & 0.0074 & 0.0058 & 0.0002 & - & - & - & - & - & 37.0 & 1.3 & - & - & - \\
\hline 5.1 & 308 & 264 & 0.86 & 3.2 & 0.000372 & 0.33 & 82.93 & 1.18 & 0.0501 & 0.0022 & 0.0120 & 0.0002 & - & - & - & - & - & 77.0 & 1.1 & - & - & - \\
\hline 6.1 & 529 & 230 & 0.44 & 5.4 & 0.000403 & 0.07 & 84.13 & 1.07 & 0.0481 & 0.0012 & 0.0119 & 0.0002 & - & - & - & - & - & 76.1 & 1.0 & - & - & - \\
\hline 7.1 & 266 & 231 & 0.87 & 11.6 & 0.000130 & 0.21 & 19.69 & 0.23 & 0.0545 & 0.0008 & 0.0507 & 0.0006 & - & - & - & - & - & 318.8 & 3.8 & - & - & - \\
\hline 8.1 & 1141 & 256 & 0.22 & 11.7 & 0.000101 & 0.24 & 83.92 & 0.95 & 0.0494 & 0.0008 & 0.0119 & 0.0001 & - & - & - & - & - & 76.2 & 0.9 & - & - & - \\
\hline 9.1 & 281 & 140 & 0.50 & 3.9 & 0.001279 & 0.22 & 62.17 & 0.85 & 0.0498 & 0.0014 & 0.0160 & 0.0002 & - & - & - & - & - & 102.6 & 1.4 & - & - & - \\
\hline 10.1 & 172 & 149 & 0.87 & 1.8 & 0.000679 & 0.43 & 80.01 & 1.34 & 0.0510 & 0.0021 & 0.0124 & 0.0002 & - & - & - & - & - & 79.7 & 1.3 & - & - & - \\
\hline 11.1 & 46 & 22 & 0.48 & 0.2 & 0.005708 & 2.82 & 173.41 & 6.37 & 0.0690 & 0.0070 & 0.0056 & 0.0002 & - & - & - & - & - & 36.0 & 1.4 & - & - & - \\
\hline 12.1 & 162 & 50 & 0.31 & 10.3 & 0.000061 & 0.14 & 13.50 & 0.17 & 0.0573 & 0.0009 & 0.0739 & 0.0010 & - & - & - & - & - & 459.9 & 5.7 & - & - & - \\
\hline 13.1 & 488 & 135 & 0.28 & 10.3 & 0.000004 & 0.25 & 40.60 & 0.48 & 0.0512 & 0.0009 & 0.0246 & 0.0003 & - & - & - & - & - & 156.5 & 1.8 & - & - & - \\
\hline 14.1 & 767 & 236 & 0.31 & 7.5 & 0.000358 & 0.07 & 87.34 & 1.04 & 0.0480 & 0.0010 & 0.0114 & 0.0001 & - & - & - & - & - & 73.3 & 0.9 & - & - & - \\
\hline 15.1 & 186 & 80 & 0.43 & 3.8 & 0.000578 & 0.20 & 41.81 & 0.59 & 0.0506 & 0.0014 & 0.0239 & 0.0003 & - & - & - & - & - & 152.1 & 2.1 & - & - & - \\
\hline 16.1 & 28 & 12 & 0.41 & 0.1 & 0.010929 & 5.69 & 168.45 & 7.73 & 0.0918 & 0.0114 & 0.0056 & 0.0003 & - & - & - & - & - & 36.0 & 1.7 & - & - & - \\
\hline 17.1 & 256 & 169 & 0.66 & 3.3 & 0.000820 & 0.36 & 66.19 & 0.94 & 0.0508 & 0.0015 & 0.0151 & 0.0002 & - & - & - & - & - & 96.3 & 1.4 & - & - & - \\
\hline 18.1 & 212 & 136 & 0.64 & 1.1 & 0.000485 & 1.04 & 172.30 & 3.10 & 0.0550 & 0.0025 & 0.0057 & 0.0001 & - & - & - & - & - & 36.9 & 0.7 & - & - & - \\
\hline 19.1 & 256 & 182 & 0.71 & 1.3 & 0.002155 & 0.46 & 169.54 & 2.79 & 0.0504 & 0.0021 & 0.0059 & 0.0001 & - & - & - & - & - & 37.7 & 0.6 & - & - & - \\
\hline 20.1 & 181 & 37 & 0.21 & 79.5 & -0.000012 & -0.02 & 1.96 & 0.02 & 0.1887 & 0.0006 & 0.5102 & 0.0057 & 13.286 & 0.153 & 0.1889 & 0.0006 & 0.963 & 2658 & 24 & 2732 & 5 & 3 \\
\hline 21.1 & 152 & 12 & 0.08 & 13.8 & -0.000249 & 0.32 & 9.45 & 0.11 & 0.0638 & 0.0007 & 0.1055 & 0.0013 & - & - & - & - & - & 646.7 & 7.5 & - & - & - \\
\hline 22.1 & 175 & 117 & 0.67 & 0.9 & 0.000000 & 1.23 & 174.46 & 3.32 & 0.0565 & 0.0028 & 0.0057 & 0.0001 & - & - & - & - & - & 36.4 & 0.7 & - & - & - \\
\hline 23.1 & 54 & 29 & 0.55 & 0.3 & 0.003065 & 3.21 & 165.85 & 5.01 & 0.0722 & 0.0058 & 0.0058 & 0.0002 & - & - & - & - & - & 37.5 & 1.2 & - & - & - \\
\hline 24.1 & 289 & 146 & 0.51 & 3.1 & 0.000485 & 0.13 & 79.85 & 1.15 & 0.0486 & 0.0013 & 0.0125 & 0.0002 & - & - & - & - & - & 80.1 & 1.2 & - & - & - \\
\hline 25.1 & 126 & 48 & 0.38 & 2.7 & -0.000443 & 0.01 & 40.80 & 0.59 & 0.0492 & 0.0015 & 0.0245 & 0.0004 & - & - & - & - & - & 156.1 & 2.3 & - & - & - \\
\hline 26.1 & 38 & 23 & 0.60 & 0.2 & 0.001547 & 5.57 & 164.77 & 5.71 & 0.0908 & 0.0078 & 0.0057 & 0.0002 & - & - & - & - & - & 36.8 & 1.3 & - & - & - \\
\hline 27.1 & 35 & 22 & 0.62 & 0.2 & 0.010348 & 5.41 & 167.22 & 6.14 & 0.0895 & 0.0078 & 0.0057 & 0.0002 & - & - & - & - & - & 36.4 & 1.4 & - & - & - \\
\hline 28.1 & 303 & 298 & 0.99 & 1.8 & -0.000375 & 0.09 & 142.33 & 2.14 & 0.0476 & 0.0018 & 0.0070 & 0.0001 & - & - & - & - & - & 45.1 & 0.7 & - & - & - \\
\hline 29.1 & 828 & 399 & 0.48 & 9.6 & 0.000078 & 0.00 & 73.87 & 0.83 & 0.0477 & 0.0007 & 0.0135 & 0.0002 & - & - & - & - & - & 86.7 & 1.0 & - & - & - \\
\hline 30.1 & 351 & 337 & 0.96 & 56.4 & -0.000011 & -0.02 & 5.35 & 0.09 & 0.0746 & 0.0023 & 0.1870 & 0.0031 & 1.928 & 0.068 & 0.0747 & 0.0023 & 0.474 & 1105 & 17 & 1062 & 63 & -4 \\
\hline 31.1 & 815 & 374 & 0.46 & 8.1 & -0.000026 & 0.10 & 86.00 & 1.01 & 0.0483 & 0.0008 & 0.0116 & 0.0001 & - & - & - & - & - & 74.5 & 0.9 & - & - & - \\
\hline 32.1 & 42 & 13 & 0.32 & 0.7 & 0.003273 & 1.50 & 54.94 & 1.24 & 0.0603 & 0.0032 & 0.0179 & 0.0004 & - & - & - & - & - & 114.5 & 2.6 & - & - & - \\
\hline 33.1 & 363 & 170 & 0.47 & 8.0 & 0.000128 & -0.03 & 39.23 & 0.46 & 0.0491 & 0.0008 & 0.0255 & 0.0003 & - & - & - & - & - & 162.3 & 1.9 & - & - & - \\
\hline 34.1 & 25 & 10 & 0.39 & 0.1 & -0.004846 & 3.53 & 162.35 & 6.80 & 0.0748 & 0.0089 & 0.0059 & 0.0003 & - & - & - & - & - & 38.2 & 1.7 & - & - & - \\
\hline 35.1 & 30 & 10 & 0.35 & 0.2 & 0.012002 & 5.01 & 167.75 & 6.69 & 0.0864 & 0.0082 & 0.0057 & 0.0002 & - & - & - & - & - & 36.4 & 1.5 & - & - & - \\
\hline 36.1 & 122 & 90 & 0.74 & 4.4 & 0.000335 & 0.22 & 23.76 & 0.32 & 0.0533 & 0.0012 & 0.0420 & 0.0006 & - & - & - & - & - & 265.2 & 3.5 & - & - & - \\
\hline 37.1 & 242 & 118 & 0.49 & 4.4 & 0.000164 & 0.34 & 47.36 & 0.60 & 0.0515 & 0.0011 & 0.0210 & 0.0003 & - & - & - & - & - & 134.2 & 1.7 & - & - & - \\
\hline 38.1 & 29 & 12 & 0.42 & 0.1 & 0.011639 & 6.18 & 172.93 & 6.93 & 0.0956 & 0.0097 & 0.0054 & 0.0002 & - & - & - & - & - & 34.9 & 1.5 & - & - & - \\
\hline 39.1 & 261 & 170 & 0.65 & 3.0 & 0.000587 & 0.00 & 73.77 & 0.99 & 0.0478 & 0.0013 & 0.0136 & 0.0002 & - & - & - & - & - & 86.8 & 1.2 & - & - & - \\
\hline 40.1 & 219 & 156 & 0.71 & 2.8 & -0.000286 & 0.13 & 66.74 & 0.92 & 0.0490 & 0.0014 & 0.0150 & 0.0002 & - & - & - & - & - & 95.7 & 1.3 & - & - & - \\
\hline 41.1 & 1115 & 856 & 0.77 & 12.7 & -0.000034 & 0.08 & 75.22 & 0.82 & 0.0484 & 0.0006 & 0.0133 & 0.0001 & - & - & - & - & - & 85.1 & 0.9 & - & - & - \\
\hline 42.1 & 193 & 45 & 0.23 & 2.7 & 0.000088 & 0.34 & 61.11 & 0.85 & 0.0508 & 0.0015 & 0.0163 & 0.0002 & - & - & - & - & - & 104.3 & 1.5 & - & - & - \\
\hline 43.1 & 421 & 287 & 0.68 & 4.3 & -0.000029 & 0.15 & 84.34 & 1.05 & 0.0487 & 0.0011 & 0.0118 & 0.0001 & - & - & - & - & - & 75.9 & 0.9 & - & - & - \\
\hline 44.1 & 464 & 23 & 0.05 & 5.3 & -0.000067 & -0.05 & 74.97 & 0.91 & 0.0474 & 0.0010 & 0.0133 & 0.0002 & - & - & - & - & - & 85.5 & 1.0 & - & - & - \\
\hline 45.1 & 286 & 159 & 0.56 & 2.6 & 0.000023 & 0.13 & 95.62 & 1.32 & 0.0483 & 0.0018 & 0.0104 & 0.0001 & - & - & - & - & - & 67.0 & 0.9 & - & - & - \\
\hline 46.1 & 358 & 196 & 0.55 & 67.1 & 0.000015 & 0.02 & 4.58 & 0.05 & 0.0842 & 0.0004 & 0.2182 & 0.0023 & 2.526 & 0.030 & 0.0840 & 0.0004 & 0.905 & 1273 & 12 & 1292 & 10 & 1 \\
\hline 47.1 & 34 & 13 & 0.38 & 0.2 & 0.005481 & 5.35 & 165.58 & 6.13 & 0.0891 & 0.0083 & 0.0057 & 0.0002 & - & - & - & - & - & 36.7 & 1.4 & - & - & - \\
\hline 48.1 & 206 & 105 & 0.51 & 1.2 & 0.002282 & 0.88 & 153.28 & 2.64 & 0.0538 & 0.0023 & 0.0065 & 0.0001 & - & - & - & - & - & 41.6 & 0.7 & - & - & - \\
\hline 49.1 & 197 & 60 & 0.31 & 2.2 & 0.000621 & 0.17 & 75.78 & 1.09 & 0.0491 & 0.0018 & 0.0132 & 0.0002 & - & - & - & - & - & 84.4 & 1.2 & - & - & - \\
\hline 50.1 & 956 & 58 & 0.06 & 9.2 & 0.000208 & 0.24 & 89.75 & 1.01 & 0.0494 & 0.0008 & 0.0111 & 0.0001 & - & - & - & - & - & 71.3 & 0.8 & - & - & - \\
\hline 51.1 & 203 & 90 & 0.44 & 2.8 & 0.000152 & 0.37 & 63.31 & 0.87 & 0.0510 & 0.0016 & 0.0157 & 0.0002 & - & - & - & - & - & 100.7 & 1.4 & - & - & - \\
\hline 52.1 & 29 & 11 & 0.39 & 0.1 & -0.002531 & 5.39 & 180.13 & 7.32 & 0.0894 & 0.0094 & 0.0053 & 0.0002 & - & - & - & - & - & 33.8 & 1.4 & - & - & - \\
\hline 53.1 & 496 & 294 & 0.59 & 8.0 & 0.000304 & 0.04 & 53.23 & 0.61 & 0.0488 & 0.0011 & 0.0188 & 0.0002 & - & - & - & - & - & 119.9 & 1.4 & - & - & - \\
\hline 54.1 & 175 & 98 & 0.56 & 3.6 & -0.000148 & 0.13 & 41.60 & 0.55 & 0.0502 & 0.0012 & 0.0240 & 0.0003 & - & - & - & - & - & 152.9 & 2.0 & - & - & - \\
\hline 55.1 & 45 & 27 & 0.60 & 0.2 & -0.001849 & 3.63 & 174.08 & 5.68 & 0.0754 & 0.0067 & 0.0055 & 0.0002 & - & - & - & - & - & 35.6 & 1.2 & - & - & - \\
\hline 56.1 & 275 & 149 & 0.54 & 5.4 & 0.000136 & 0.20 & 43.94 & 0.54 & 0.0505 & 0.0010 & 0.0227 & 0.0003 & - & - & - & - & - & 144.8 & 1.8 & - & - & - \\
\hline 57.1 & 133 & 107 & 0.81 & 1.4 & 0.000304 & 0.05 & 79.93 & 1.32 & 0.0480 & 0.0020 & 0.0125 & 0.0002 & - & - & - & - & - & 80.1 & 1.3 & - & - & - \\
\hline 58.1 & 197 & 97 & 0.49 & 1.0 & 0.000378 & 0.43 & 174.19 & 3.19 & 0.0502 & 0.0026 & 0.0057 & 0.0001 & - & - & - & - & - & 36.7 & 0.7 & - & - & - \\
\hline 59.1 & 105 & 67 & 0.63 & 1.9 & 0.000112 & 0.39 & 47.17 & 0.73 & 0.0518 & 0.0017 & 0.0211 & 0.0003 & - & - & - & - & - & 134.7 & 2.1 & - & - & - \\
\hline 60.1 & 195 & 129 & 0.66 & 1.0 & 0.000576 & 1.34 & 173.14 & 3.10 & 0.0574 & 0.0026 & 0.0057 & 0.0001 & - & - & - & - & - & 36.6 & 0.7 & - & - & - \\
\hline
\end{tabular}


Appendix II continued.

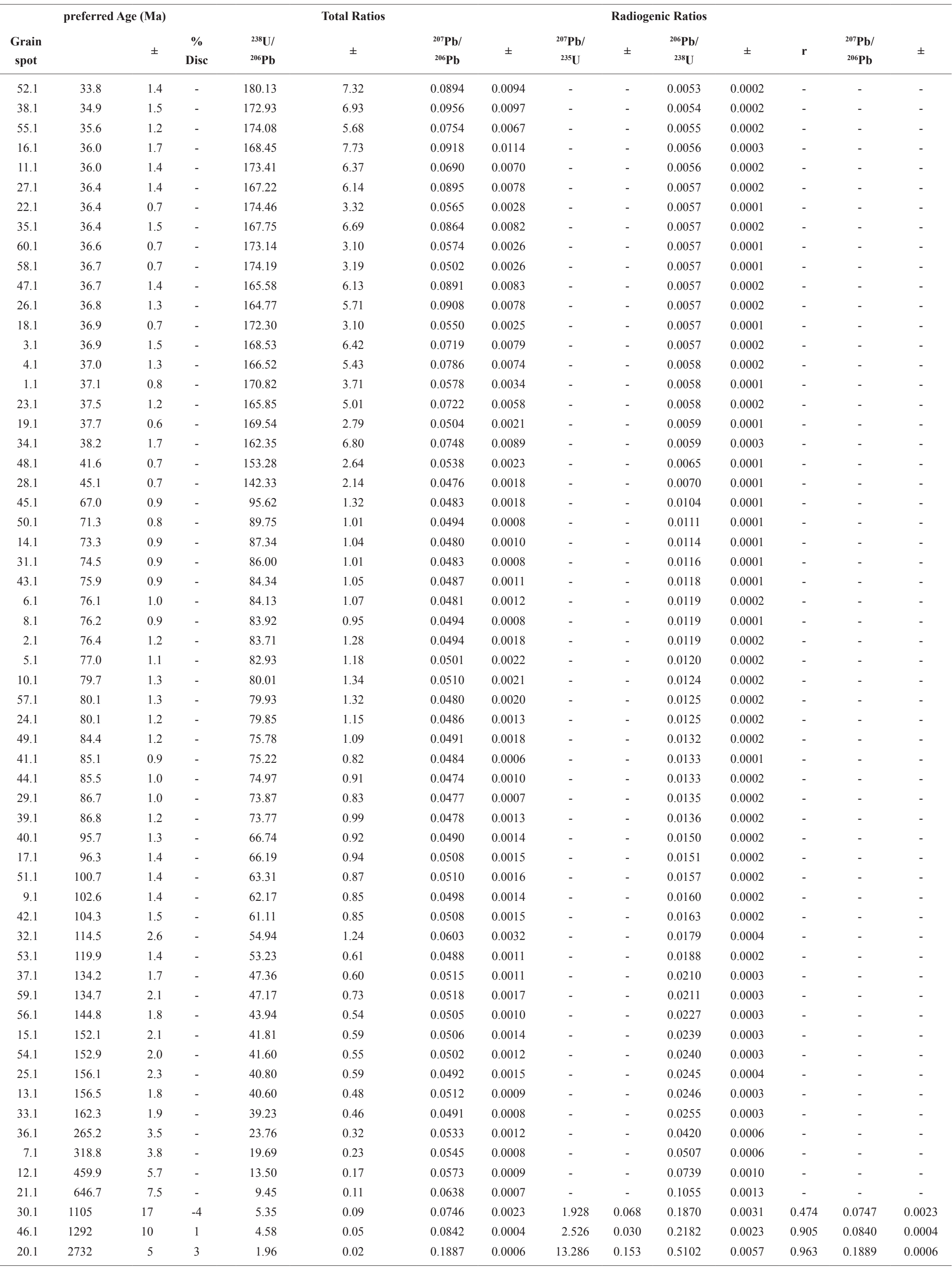

NOTES :

1. Uncertainties given at the one s level.

2. Error in Temora reference zircon calibration was $0.62 \%$ for the analytical session (not included in above errors but required when comparing ${ }^{206} \mathrm{~Pb} /{ }^{238} \mathrm{U}$ data from different mounts).

3. $\mathrm{f} \%$ denotes the percentage of ${ }^{206} \mathrm{~Pb}$ that is common $\mathrm{Pb}$.

4. For areas older than $\sim 800 \mathrm{Ma}$ correction for common $\mathrm{Pb}$ made using the measured ${ }^{204} \mathrm{~Pb} / 206 \mathrm{~Pb}$ ratio.

5. For areas younger than $\sim 800 \mathrm{Ma}$ correction for common $\mathrm{Pb}$ made using the measured ${ }^{238} \mathrm{U} /{ }^{206} \mathrm{~Pb}$ and ${ }^{207} \mathrm{~Pb} /{ }^{206} \mathrm{~Pb}$ ratios following Tera and Wasserburg (1972) as outlined in Williams (1998). 6. For $\%$ Disc, $0 \%$ denotes a concordant analysis. 